\title{
Effects of interventions promoting monitoring of medication use and brief messaging on medication adherence for people with type 2 diabetes: systematic review of randomised trials
}

DOI:

10.1111/dme.12987

\section{Document Version}

Accepted author manuscript

Link to publication record in Manchester Research Explorer

\section{Citation for published version (APA):}

Farmer, A. J., Mc Sharry, J., Rowbotham, S., Mcgowan, L., Ricci-Cabello, I., \& French, D. P. (2016). Effects of interventions promoting monitoring of medication use and brief messaging on medication adherence for people with type 2 diabetes: systematic review of randomised trials. Diabetic Medicine. https://doi.org/10.1111/dme.12987

\section{Published in:}

Diabetic Medicine

\section{Citing this paper}

Please note that where the full-text provided on Manchester Research Explorer is the Author Accepted Manuscript or Proof version this may differ from the final Published version. If citing, it is advised that you check and use the publisher's definitive version.

\section{General rights}

Copyright and moral rights for the publications made accessible in the Research Explorer are retained by the authors and/or other copyright owners and it is a condition of accessing publications that users recognise and abide by the legal requirements associated with these rights.

\section{Takedown policy}

If you believe that this document breaches copyright please refer to the University of Manchester's Takedown Procedures [http://man.ac.uk/04Y6Bo] or contact uml.scholarlycommunications@manchester.ac.uk providing relevant details, so we can investigate your claim.

\section{OPEN ACCESS}




\section{DIABETIC Medicine \\ DAABEIES UK
CARE. CONNECT. CAMPACGN.}

\section{Effects of interventions promoting monitoring of medication use and brief messaging on medication adherence for people with type 2 diabetes: systematic review of randomised trials}

\begin{tabular}{|r|l|}
\hline Journal: & Diabetic Medicine \\
\hline Manuscript ID: & DME-2015-00451.R1 \\
\hline Manuscript Type: & Systematic Review or Meta-analysis \\
\hline Complete List of Authors: & $\begin{array}{l}\text { Farmer, Andrew; University of Oxford, Department of Primary Health Care } \\
\text { Mc Sharry, Jennifer; NUI Galway, School of Psychology } \\
\text { Rowbotham, Samantha; University of Manchester, School of Psychological } \\
\text { Sciences } \\
\text { McGowan, Laura; University of Manchester, School of Psychological } \\
\text { Sciences } \\
\text { Ricci-Cabello, Ignacio; University of Oxford, Nuffield Department of } \\
\text { Primary Care Health Sciences } \\
\text { French, David; University of Manchester, School of Psychological Sciences }\end{array}$ \\
\hline Keywords: & $\begin{array}{l}\text { adherence, systematic reviews, health care delivery, patient education, } \\
\text { therapy, type 2 diabetes }\end{array}$ \\
\hline
\end{tabular}


TITLE: Effects of interventions promoting monitoring of medication use and brief messaging on medication adherence for people with type 2 diabetes: systematic review of randomised trials

RUNNING HEAD: Monitoring and brief messaging to support medicines adherence

\author{
AUTHORS: A.J Farmer ${ }^{1}$, J. McSharry ${ }^{2,3}$, S. Rowbotham ${ }^{3}$, L. McGowan ${ }^{3}$ I. Ricci- \\ Cabello $^{1} \&$ D.P. French ${ }^{3}$ \\ ${ }^{1}$ Nuffield Department of Primary Care Health Sciences, University of Oxford, Oxford, \\ UK \\ ${ }^{2}$ National University of Ireland, Galway, Ireland \\ ${ }^{3}$ University of Manchester, Manchester, UK
}

CORRESPONDING AUTHOR: David P. French (david.french@manchester.ac.uk)

\begin{abstract}
249
WORD COUNT: 3,465

FUNDING: This work was funded through an NIHR Senior Investigator Award to A J Farmer.
\end{abstract}

CONFLICTS OF INTEREST: All authors confirm that they have no conflicts of interest 


\section{ABSTRACT}

Aims

We aimed to assess the impact of interventions promoting monitoring of medication use and brief messaging to support medication adherence in patients with Type 2 diabetes mellitus (DM), and investigate the extent of theory use to guide intervention development.

Methods

We systematically searched for controlled trials, published from 1990 onwards in Medline, Embase, CINAHL, PsycINFO and Cochrane library, evaluating interventions based on monitoring and brief messaging to support medication adherence in Type 2 DM patients, to examine their effectiveness.

Results

Eleven trials (comparing fifteen interventions) were identified. Only a small minority presented a low risk of bias. Three interventions were based on delivering brief messages, six on monitoring medication adherence, and six used both strategies. Messaging interventions included use of SMS text-messages, web-based feedback, and messages delivered through monitoring devices. Monitoring interventions included remote self-reporting of medication and telephone calls with healthcare staff. Improvements in medication adherence were observed in six interventions, although effect sizes were generally moderate. Only two interventions improved both adherence and clinical outcomes. A meta-analysis of five trials (eight interventions) combining monitoring and messaging strategies showed that the pooled difference in medication adherence between intervention and control was moderate and not statistically significant (standardised mean difference $=0.22[95 \%$ confidence interval $-0.05 ; 0.49])$. Only four trials were based on explicit theoretical frameworks.

\section{Conclusions}

Although interventions based on messaging and monitoring have potential to improve medication adherence in Type 2 DM patients, evidence on their efficacy is limited and additional high-quality, theory-based research is needed. 


\section{INTRODUCTION}

Up to $37 \%$ of patients with Type 2 diabetes mellitus (DM) stop using oral glucose lowering drugs within one year of starting treatment [1]. This is problematic as medication non-adherence is associated with poor clinical outcomes [2] and, in the United States, increased health care costs of up to one billion dollars [3].

Across all patient groups, evidence for effective interventions that can support patients in taking their medication is inconsistent and only a minority of trials, at low risk of bias, show improvement in adherence and clinical outcomes [4]. Similar findings have been found in systematic reviews focussing on adherence in patients with diabetes [5-9]. Increasingly, interventions are complex, addressing multiple factors, using behavioural, affective and provider focussed components [10]. Consequently, the costs of such interventions can be high involving face-to-face support and counselling.

A range of promising novel interventions utilising Internet or telephone-based support are now being identified for use in supporting diabetes self-management [11, 12]. They have the potential to deliver interventions at low-cost and wide-scale. However, since there are many possible intervention components that could be delivered in this way, it is important to identify which components of behaviour change interventions are most effective.

Information technology can be used to deliver brief automated messages through a variety of platforms including short message service (SMS) text messaging and interactive voice recognition $[13,14]$. The potential for SMS messages to target a range of behavioural determinants of adherence to medication is clearly demonstrated in studies focussing on other long-term conditions [15-17]. Messages can be used to provide motivation, practical hints and tips about routines, cues to new behaviours, and social support [14, 18]. They can also be linked to monitoring of symptoms [19] or physiological parameters [20] to personalise messages and determine their timing.

Similarly, interventions that involve monitoring of medicines offer feedback to patients, can be used to target patient-level interventions at high-risk individuals and drive provider-focussed interventions [4, 21]. Aggregated data on prescribing and other direct patient monitoring techniques has potential to support adherence [19, 
20], although individual-level feedback may be used. For example, contacting patients who did not fill their first prescription for a lipid lowering treatment increased medicine collection by $16 \%$, with effects persisting for up to a year [22].

There is limited evidence for effectiveness of monitoring and messaging interventions for individuals with HIV, hypercholesterolemia and hypertension [14, $17,20]$, including evidence of clinically relevant benefit from lower blood pressure.

The low-cost, scalable nature of brief messaging and monitoring interventions make them worth exploring to improve adherence in diabetes. There is evidence that specific beliefs and concerns associated with taking medication for diabetes may differ from beliefs and concerns held by people with other conditions [23]. To guide future research, the extent, content, and theoretical basis of interventions that have been tested in trials to date needs to be identified and characterised before further research to optimise existing interventions or develop new ones, and then and explore when, in what circumstances, and to what extent they are effective.

We aimed to examine the effectiveness of interventions for people with Type 2 DM in increasing medication adherence and improving glycated haemoglobin (HbA1c), that include (i) monitoring of medication adherence by self or others or (ii) delivery of brief messages intended to support taking medicines. We also aimed to assess the extent theory was used in the development of the included interventions. 


\section{METHODS}

We carried out a systematic review of published controlled trials, including trials with non-randomised comparison groups. The review and its procedures were planned, conducted, and reported according to standard recommendations [24].

\section{Inclusion Criteria}

\section{Interventions}

Eligible interventions were those intended to support taking medicines containing either a monitoring or a brief messaging component, often as part of a complex and multi-component intervention. Monitoring of medication adherence was defined as repeated observations over time of the degree to which the person's behaviour corresponds with the recommendations agreed with a health care provider.

Monitoring included monitoring of medications by self or others and as an explicitly stated intervention component. Brief messaging interventions were defined as messages delivered remotely, handled with algorithms or rule based systems, and where delivered by a clinician or other individual, followed a prescribed and scripted set of responses without requiring individual judgment about message content.

\section{Comparisons}

Trials were included where a usual care or control group received no intervention, or an alternative intervention that did not involve monitoring or brief messages.

\section{Participants}

We included trials targeted at adults with Type 2 DM who were prescribed any of the following medications: i) medication to reduce micro and macro-vascular risk, including oral or injectable drugs to reduce blood glucose levels, ii) medication to lower blood pressure, or iii) medication to lower lipids.

\section{Outcomes}

Trials using objective or subjective (patient-reported) measures as either primary or secondary outcome measures were included. Trials reporting a proxy measurement 
of medication adherence (such as prescribing or dispensing data, or information about initial or subsequent medication) were included.

\section{Exclusion Criteria}

Trials were excluded if they i) had mixed populations of Type 1 and Type 2 DM where the findings from each population could not clearly be distinguished, ii) examined interventions based on blogs or social interaction, iii) were published before January 1990, or iv) were published only in the form of conference abstracts. We did not restrict inclusion by the type of professionals delivering the interventions or type of medications.

\section{Searches}

Searches were conducted in December 2014 in Medline, EMBASE, Psyclnfo, CINAHL, and the Cochrane Register (online appendix 1). Search strategies were developed by modifying MeSH and keywords used in previously published systematic reviews [25-28].

\section{Additional Searches}

Relevant previously published reviews [29-32] were examined for additional trials. Forward and backward citation searches were conducted on all included articles.

\section{Screening}

Titles and abstracts were screened based on the participant, comparison and outcome inclusion and exclusion criteria outlined above. A subsequent review of the abstracts was carried out to identify i) trials of brief messaging interventions, and ii) trials evaluating monitoring.

Screening by titles and abstracts was conducted by SR, with a random sample of $10 \%$ also double screened by JMcS. Full text screening was independently undertaken by SR and AF. Where there was uncertainty, trials were discussed with the whole research team until agreement was reached. 


\section{Data extraction, quality assessment and use of theory}

Data extraction, using structured forms, included: trial design, number of participants in each group, length of follow-up, key elements of the intervention, type of comparison group, adherence measures used, and impact of the intervention on medication adherence and clinical outcomes. We used the Cochrane collaboration's tool for risk of bias assessment [27].

The extent to which the trials used explicit theory was assessed using the coding scheme proposed by Michie and Prestwich [33]. The coding-scheme contains 19 items to assess whether a theory was mentioned, how theories were used in intervention design and in the selection of intervention techniques, how intervention evaluations tested theory and the implications of the results for future theory development.

Risk of bias and use of theory was independently appraised by two reviewers (SR and LMcG). We quantified reviewer agreement on trial 'risk of bias' and 'use of theory' criteria using the Cohen's kappa coefficient [34]. Disagreements were discussed until consensus was reached.

\section{Data synthesis and analysis}

The main results of the studies were summarized and classified into three groups: monitoring interventions, brief messages interventions and interventions including both components. Where possible, we pooled data to summarize the difference in change in medication adherence from baseline to the end of the trial between intervention and control groups. We anticipated that included trials would vary in their setting, intervention and design, so we used a random effects model to pool data [35]. The patient-reported measures for medication adherence also varied between trials so we used Cohen's method to calculate pooled effect sizes [36] based on standardized mean difference (SMD). We standardized scores where required so that higher scores indicated higher levels of adherence [36]. Where the standard deviation (SD) of the change between intervention and control group for an outcome was not provided, we derived them from baseline and final SDs, assuming a degree of correlation of 0.5 [37]. A sensitivity analysis was undertaken using different values 
of correlation to determine whether the overall result of the analysis were robust to the use of imputed correlation coefficients. Heterogeneity was quantified by the $\mathrm{I}^{2}$ statistic, where I $>50 \%$ was considered evidence of substantial heterogeneity [38]. Publication bias was examined with funnel plots and presence of asymmetry tested with Begg [39] and Egger tests [40]. Meta-analyses were conducted with Stata, version 12.0. We set a threshold of $P=0.05$ to accept statistical significance. 


\section{RESULTS}

\section{Trial identification}

The initial database search identified 1,833 references, of which 545 were duplicates (Fig. 1). Title and abstract screening identified 78 references (overall agreement between reviewers was 91\%; kappa $=0.51$ ). Following full text screening, 23 articles (including trial protocols and clinical trial registry entries) were included. Where a single trial was reported in more than one article, data from all those articles were combined. 11 separate trials examined the effectiveness of 15 separate interventions (four of the trials examined two interventions each). No additional eligible trials were identified as a result of the backward and forward searching.

\section{FIGURE 1 ABOUT HERE}

\section{Characteristics of the interventions}

Key characteristics of included interventions are reported in Table 1. Three interventions were based on brief messages (three trials [41-43]), six interventions based on monitoring (six trials [31, 44-52]), and six combined both strategies (four trials [31, 48-56]).

Interventions based solely on brief messages were delivered via SMS textmessage [41-43], whereas the messages in those interventions combining messaging and monitoring strategies were delivered by SMS text-message [31, 4850], and by web-based systems [53-56] or monitoring devices [51, 52]. Monitoring interventions included remote self-reporting of medication use [48-56] and telephone calls to patients from healthcare staff $[44,46,47,53-56]$.

All eleven trials identified examined the impact of the interventions on medication adherence. There was substantial heterogeneity in reporting of adherence as a trial outcome. Thirteen different outcome measures were reported (listed in Table 1 and online appendix 2). Most were patient-reported, but electronic monitoring and measures based on pharmacy data were also reported. 


\section{TABLE 1 ABOUT HERE}

\section{Risk of bias}

Agreement was high in assessing risk of bias (kappa $=0.83$ ). Only a small minority of the trials had a low risk of bias, and none were assessed as free of bias (Figs. 23 ), although all randomly allocated participants between groups.

Most frequent risks were related to blinding of participants and personnel to the interventions with blinding of outcome assessment considered inadequate in seven studies due to the use of self-reported measures of medication adherence.

\section{FIGURES 2 \& 3 ABOUT HERE}

\section{Effectiveness of the interventions on medication adherence}

The impact of interventions on medication adherence is reported in Table 2. Most of the trials measured adherence to all types of medications prescribed to patients with type 2 DM (including diabetes specific medication but also other types of medication such as anti-hypertensive or antidepressant). Only a minority [31, 42, 44, 48-50] focused on specific types of medication, which included a combination of oral hypoglycaemic agents, antidepressant medications or medications for high cholesterol and hypertension.

The three trials exclusively based on messaging reported improved medication adherence, although the magnitude of the effects and their statistical significance were unclear [41-43].

Three of the six trials examining the impact of interventions exclusively based on monitoring observed improvements in medication adherence [44-46], whereas three trials found no effect [31, 47-52]. 
Two trials examining the impact of interventions including both messages and monitoring components observed a positive impact on medication adherence [31, $48-50,53]$. The remaining two trials $[51,52,54-56]$ reported no significant differences in medication adherence between intervention and control groups.

Data from five trials with self-reported adherence measures $[41,46,52,53,56]$ were pooled in a meta-analysis (Fig. 4). The five trials included eight comparisons assessing the impact of messages alone, or a combination of monitoring and messages. The pooled difference in change in adherence between intervention $(n=754)$ and control groups $(n=377)$ was estimated. The SMD between intervention and control groups was 0.22 (95\% confidence interval -0.05 to 0.49$)$ and not significant. Heterogeneity among the trials was high $\left(\mathrm{I}^{2}=77.3 \%\right)$. Interventions focused on the use of SMS text-messages appeared to be more effective than those interventions combining messages and monitoring strategies $(0.95[-0.13 ; 2.03]$ vs $0.03[-0.10 ; 0.17]$, respectively). Sensitivity analysis confirmed that the overall result was robust to the use of imputed correlation coefficients. Egger and Begg tests for funnel plot asymmetry (Appendix 3 ) were significant $(P=0.004$ and $P=0.003$ respectively) although the analysis included a single trial [46] reporting large effects in medication adherence with a low number of participants.

\section{FIGURE 4 ABOUT HERE}

\section{Effectiveness of the interventions on clinical outcomes}

Three trials examined the impact of message interventions on clinically relevant outcomes (Table 2). One reported a difference in $\mathrm{HbA} 1 \mathrm{c}$ between intervention and control groups of $5 \mathrm{mmol} / \mathrm{mol}(\mathrm{HbA} 1 \mathrm{c}=0.5 \%)$ [41]. In another [42], mean blood pressure, and total and LDL cholesterol concentrations improved, but not fasting plasma glucose, HbA1c or weight. In a third [43], the percentage of patients with less than $64 \mathrm{mmol} / \mathrm{mol}(\mathrm{HbA} 1 \mathrm{c}<8.0 \%)$ increased over one year.

With the exception of one trial [31, 48-50], all the trials of interventions evaluating monitoring without messages reported clinically relevant outcomes. One [44], 
reported that patients allocated to receive the intervention were more likely to achieve target $\mathrm{HbA} 1 \mathrm{c}$ levels and improved mood. Another [46], reported significant improvements in $\mathrm{HbA1c}$. A third $[51,52]$, reported that a low-intensity intervention (including only monitoring but not message reminders) significantly decreased $\mathrm{HbA1c}$, but not blood pressure. Two other trials [45, 47] did not observe differences between the intervention and control.

Three trials evaluated the impact of interventions combining monitoring and messages on clinical outcomes. In one [53], no effect was observed on HbA1c levels. In another [54-56], consistent, modest improvements in HbA1c, lipidaemia, blood pressure, and 10 year coronary heart disease were observed, but betweengroup differences were not statistically significant on any of the measures. Finally another trial $[51,52]$ observed that the high-intensity intervention (including both monitoring and message reminders) significantly decreased $\mathrm{HbA} 1 \mathrm{c}(-5 \mathrm{mmol} / \mathrm{mol}$ $(0.4 \%) ; P<0.05)$, and systolic blood pressure $(-6.05 \mathrm{mmHg} ; P<0.05)$.

TABLE 2 ABOUT HERE

\section{Use of theory in included studies}

Only four out of the eleven trials [31, 41, 44, 48-50, 54-56] explicitly reported that the interventions used were based on theory. Each of the four trials reported using a different theoretical framework. One intervention [41] was based on the Health Belief Model [57]. Another primary-care trial [44] used an intervention development framework based on the Theory of Reasoned Action [58, 59]. Another primary-care trial included two interventions [54-56], both based on social cognitive theory, selfefficacy and the application of social-ecologic approaches to health issues [60]. A fourth trial based in community pharmacies $[51,52]$ used an intervention based on behavioural learning theory, drawn from wider theoretical perspectives on adherence [61]. 
Table 3 describes the extent to which the trials explicitly used theory in relation to a number of criteria [33]. Reviewer agreement on whether theory was used in the interventions was high (kappa= 0.97). Theory was explicitly mentioned in only four trials, and even then, there was variation in how thoroughly it was used (online appendix 4). For example, two of these four trials [31, 48-50, 54-56] presented evidence that the psychological constructs planned as targets for trial interventions were predictors of behaviour (criterion 2). None of the articles reported carrying out a mediational analysis of constructs or discussed the results in relation to theory.

\section{TABLE 3 ABOUT HERE}




\section{DISCUSSION}

This systematic review has identified six of eleven trials targeted at people with Type $2 \mathrm{DM}$, based on messaging or monitoring or both, that report small but statistically significant effect sizes for improvement in adherence when tested against a comparator. Pooled data from five trials using self-reported measures reported a small, non-significant standard mean difference in adherence. Only a small minority of the trials to-date have a low risk of bias and interventions are rarely based on explicit theoretical frameworks. The interventions used a wide variety of technical approaches including SMS text-messages, web based feedback; different ways of trying to change behaviour including prompts and informational messages; and different degrees of support from health care staff including remote self-reporting of medication and telephone calls from healthcare staff.

This is the first study to systematically examine and synthesise reports of trials examining the effectiveness of messaging and monitoring based interventions on adherence to medication in patients with Type $2 \mathrm{DM}$. Although this review has been carried out using rigorous methods, the findings are limited by the risk of bias in the findings of the majority of trials. The extent to which the interventions were developed and optimised for their setting is unclear, and the self-reported measures used may not be reliable [62]. Although tests for funnel plot asymmetry, intended to explore whether there might be missing trials, were positive, this may have been a chance finding resulting from the small number of interventions included in the analysis.

Previous systematic reviews have examined a number of different strategies to improve adherence to diabetes medication. Some interventions have focused on the use of educational approaches [5], others on interventions delivered by specific providers (e.g. pharmacists [7, 8] or nurses [63]) and others have used a broader approach, reviewing healthcare interventions to support medication adherence in patients with Type 2 DM $[6,10,64]$. In general these reviews offer a similar message to our own review: although some of the interventions led to improvements in 
medication adherence and clinical outcomes, the results are inconsistent, and there is no evidence of superiority for any of the types of interventions tested.

\section{Despite a strong rationale for exploring monitoring and messaging, particularly} following evidence from management of individuals with hypertension, antiretroviral therapy for HIV and smoking cessation, $[14,17]$, it is clear that brief messaging interventions in diabetes have not been evaluated using well developed and characterised interventions, or with rigorous trial designs. Future trials would therefore benefit from formative work to develop interventions and embed them in clinical care pathways, the use of objective measures of medicine adherence [4], and work to further understand how to optimise the use of messaging to lead to changes in behaviour. Given the increasing evidence supporting the use of multifaceted interventions [4, 10], the aim of this type of research is however to deliver these interventions at sufficiently low cost that they can be delivered alongside, and further improve the effectiveness, of other interventions.

A wide range of self-reported outcome measures are used in the trials included in this review. However, evidence underpinning the validity and reliability for some is not strong [62]. For example, where individuals receive coaching in the need to take medications, there is a strong possibility of differential reporting of adherence to medication compared with individuals receiving usual care. Routinely collected data about prescribing can be used to monitor adherence and is non-intrusive, although care needs to be taken with the precise metric derived from the prescribing record [65]. Electronic medication monitoring $[66,67]$ is widely used, but can be seen as intrusive and is currently costly for routine use in clinical practice.

Some approaches to monitoring have strong face-validity, for example checking electronic records to see whether a patient continues to obtain prescriptions for medication and making contact to enquire the reason. However, automated systems to manage this task are not widely implemented despite research demonstrating its potential to reduce non-adherence in other conditions [22]. Although messages and 
thresholds for making contact with patients would need to be optimised, adopting this approach could have immediate utility.

A challenge facing future intervention development in this area is the need for well-designed process evaluations to explore whether an intervention, designed to change behaviour and outcomes, is successful in changing the proposed mechanism through which change in behaviour could be brought about. There is an increasing recognition that progress in developing an evidence base for behaviour change interventions can be enhanced by applying theory, as it focusses attention on the mechanisms through which interventions might be effective [68]. As in the wider literature, we observe that the majority of interventions do not involve theory based development, and in those that have applied theory to develop the intervention, it was not use to refine the intervention, to examine process measures that might indicate effect, or refine it subsequently. We need to develop a better understanding of mechanisms of change and develop a basis for refining and developing better theory [69].

In conclusion, although interventions based on messaging and monitoring could appear promising to improve medication adherence in patients with Type $2 \mathrm{DM}$ at low cost, good evidence is still scarce and more high-quality theory-based research is needed. 


\section{FUNDING}

This work was funded through an NIHR Senior Investigator Award to A J Farmer.

\section{CONFLICTS OF INTEREST}

All authors confirm that they have no conflicts of interest

\section{ACKNOWLEDGEMENTS}

AF receives additional research funding from the Oxford NIHR Biomedical Research Centre. 


\section{REFERENCES}

1. Hertz RP, Unger AN, Lustik MB. Adherence with pharmacotherapy for type 2 diabetes: a retrospective cohort study of adults with employer-sponsored health insurance. Clin Ther 2005; 27: 1064-73.

2. Pladevall M, Williams LK, Potts L A, Divine G, Xi H, Lafata J E. Clinical outcomes and adherence to medications measured by claims data in patients with diabetes. Diabetes Care 2004; 27: 2800-5.

3. Egede LE, Gebregziabher M, Dismuke CE, Lynch CP, Axon RN, Zhao Y, et al. Medication Nonadherence in Diabetes: Longitudinal effects on costs and potential cost savings from improvement. Diabetes Care. 2012 35:2533-9.

4. Nieuwlaat R, Wilczynski N, Navarro T, Hobson N, Jeffery R, Keepanasseril A, et al. Interventions for enhancing medication adherence. Cochrane Database Syst Rev 2014; 11: CD000011.

5. Wens J, Vermeire E, Hearnshaw H, Lindenmeyer A, Biot Y, Van Royen P. Educational interventions aiming at improving adherence to treatment recommendations in type 2 diabetes: A sub-analysis of a systematic review of randomised controlled trials. Diabetes Res Clin Pract 2008;79:377-88.

6. Sapkota S, Brien JA, Greenfield J, Aslani P. A systematic review of interventions addressing adherence to anti-diabetic medications in patients with type 2 diabetes--impact on adherence. PLoS One 2015;10:e0118296.

7. Omran D, Guirguis LM, Simpson SH. Systematic Review of Pharmacist Interventions to Improve Adherence to Oral Antidiabetic Medications in People with Type 2 Diabetes. Can J Diabetes 2012;36:292-9.

8. Lindenmeyer A, Hearnshaw H, Vermeire E, Van Royen P, Wens J, Biot Y. Interventions to improve adherence to medication in people with type 2 diabetes 
mellitus: a review of the literature on the role of pharmacists. J Clin Pharm Ther 2006;31:409-19.

9. Doggrell SA. Does intervention by an allied health professional discussing adherence to medicines improve this adherence in Type 2 diabetes? Diabet Med 2010;27:1341-9.

10. Sapkota S, Brien JA, Greenfield JR, Aslani P. A Systematic Review of Interventions Addressing Adherence to Anti-Diabetic Medications in Patients with Type 2 Diabetes-Components of Interventions. PLoS One 2015;10:e0128581. 11. Graziano JA, Gross CR. The effects of isolated telephone interventions on glycemic control in type 2 diabetes: a literature review. ANS Adv Nurs Sci 2009;32:E28-41.

12. van Dam HA, van der Horst FG, Knoops L, Ryckman RM, Crebolder HF, van den Borne BH. Social support in diabetes: a systematic review of controlled intervention studies. Patient Educ Couns 2005;59:1-12.

13. Michie S, van Stralen MM, West R. The behaviour change wheel: a new method for characterising and designing behaviour change interventions. Implement Sci 2011;6:42.

14. Free C, Phillips G, Galli L, Watson L, Felix L, Edwards P, et al. The effectiveness of mobile-health technology-based health behaviour change or disease management interventions for health care consumers: a systematic review. PLoS Med 2013;10:e1001362.

15. de Tolly K, Skinner D, Nembaware V, Benjamin P. Investigation into the use of short message services to expand uptake of human immunodeficiency virus testing, and whether content and dosage have impact. Telemed J E Health 2012;18:18-23. 
16. Lester RT, Ritvo P, Mills EJ, Kariri A, Karanja S, Chung MH, et al. Effects of a mobile phone short message service on antiretroviral treatment adherence in Kenya (WelTel Kenya1): a randomised trial. Lancet 2010;376:1838-45.

17. Leon N, Surender R, Bobrow K, Muller J, Farmer A. Improving treatment adherence for blood pressure lowering via mobile phone SMS-messages in South Africa: a qualitative evaluation of the SMS-text Adherence SuppoRt (StAR) trial. BMC Fam Pract 2015;16:80.

18. Heron KE, Smyth JM. Ecological Momentary Interventions: Incorporating Mobile Technology Into Psychosocial and Health Behavior Treatments. Br J Health Psychol 2010;15:1-39.

19. Miklowitz DJ, Price J, Holmes EA, Rendell J, Bell S, Budge K, et al. Facilitated Integrated Mood Management for adults with bipolar disorder. Bipolar Disord 2012; 14: $185-97$.

20. Carrasco MP, Salvador CH, Sagredo PG, Marquez-Montes J, Gonzalez de Mingo MA, Fragua JA, et al. Impact of patient-general practitioner short-messagesbased interaction on the control of hypertension in a follow-up service for low-tomedium risk hypertensive patients: a randomized controlled trial. IEEE Trans Inf Technol Biomed 2008; 12: 780-91.

21. Kass MA, Meltzer DW, Gordon M. A miniature compliance monitor for eyedrop medication. Arch Ophthalmol 1984;102:1550-4.

22. Derose SF, Green K, Marrett E, et al. Automated outreach to increase primary adherence to cholesterol-lowering medications. JAMA Intern Med 2013;173:38-43.

23. Farmer A, Kinmonth AL, Sutton S. Measuring beliefs about taking hypoglycaemic medication among people with Type 2 diabetes. Diabet Med 2006;23:265-70. 
24. Moher D, Liberati A, Tetzlaff J, Altman DG. Preferred Reporting Items for Systematic Reviews and Meta-Analyses: The PRISMA Statement. Ann Intern Med 2009; 151: 264-9.

25. Welschen LM, Bloemendal E, Nijpels G, Dekker JM, Heine RJ, Stalman WA, et al. Self-monitoring of blood glucose in patients with type 2 diabetes mellitus who are not using insulin. Cochrane Database Syst Rev 2012 18; 1: CD005060.

26. Haynes RB, Ackloo E, Sahota N, McDonald HP, Yao X. Interventions for enhancing medication adherence. Cochrane Database Syst Rev 2008; 16(2): CD000011

27. Higgins JPT, Green S. Cochrane Handbook for Systematic Reviews of Interventions: The Cochrane Collaboration; 2011. Available from: www.cochranehandbook.org. Last accessed 6 August 2015.

28. Olander EK, Fletcher H, Williams S, Atkinson L, Turner A, French DP. What are the most effective techniques in changing obese individuals' physical activity selfefficacy and behaviour: a systematic review and meta-analysis. Int J Behav Nutr Phys Act 2013; 10: 29.

29. Cassimatis M, Kavanagh DJ. Effects of type 2 diabetes behavioural telehealth interventions on glycaemic control and adherence: a systematic review. J Telemed Telecare 2012; $18: 447-50$.

30. Ryan R, Santesso N, Lowe D, Hill S, Grimshaw J, Prictor M, et al. Interventions to improve safe and effective medicines use by consumers: an overview of systematic reviews. Cochrane Database Syst Rev 2014; 4: CD007768.

31. Vervloet M, Linn AJ, van Weert JCM, de Bakker DH, Bouvy ML, van Dijk L. The effectiveness of interventions using electronic reminders to improve adherence 
to chronic medication: a systematic review of the literature. J Am Med Inform Assoc 2012; 19: 696-704.

32. Williams JLS, Walker RJ, Smalls BL, Campbell JA, Egede LE. Effective interventions to improve medication adherence in Type 2 diabetes: a systematic review. Diabetes Manag (Lond) 2014; 4: 29-48.

33. Michie S, Prestwich A. Are interventions theory-based? Development of a theory coding scheme. Health Psychol 2010; 29: 1-8.

34. Fleiss JL, Levin B, Cho Paik. Statistical methods for rates and proportions (3rd edn) John Wiley \& Sons, 2013.

35. DerSimonian R, Laird N. Meta-analysis in clinical trials. Control Clin Trials. 1986; $7: 177-88$.

36. Cohen J. Weighted kappa: Nominal scale agreement provision for scaled disagreement or partial credit. Psychol Bull 70; 213.

37. Rice J. Mathematical Statistics and Data Analysis. Cengage Learning 2006.

38. Deeks J, Higgins J, Altman D. Chapter 9-Analysing Data and Undertaking Meta-analyses. The Cochrane Collaboration; 2011. Available from: www.cochranehandbook.org. Last accessed 6 August 2015..

39. Begg CB, Mazumdar M. Operating characteristics of a rank correlation test for publication bias. Biometrics. 1994; 50: 1088-101.

40. Egger M, Smith GD, Schneider M, Minder C. Bias in meta-analysis detected by a simple, graphical test. BMJ 1997; 315: 629-34.

41. Arora S, Peters AL, Burner E, Lam CN, Menchine M. Trial to examine text message-based mHealth in emergency department patients with diabetes (TExTMED): a randomized controlled trial. Ann Emerg Med 2014; 63: 745-54. 
42. Brath H, Morak J, Kastenbauer T, Modre-Osprian R, Strohner-Kastenbauer H, Schwarz M, et al. Mobile health (mHealth) based medication adherence measurement: a pilot trial using electronic blisters in diabetes patients. $\mathrm{Br} \mathrm{J}$ Clin Pharmacol 2013; 76: 47-55.

43. Shetty AS, Chamukuttan S, Nanditha A, Raj RK, Ramachandran A. Reinforcement of adherence to prescription recommendations in Asian Indian diabetes patients using short message service (SMS): a pilot study. J Assoc Physicians India 2011;59:711-4.

44. Bogner HR, Morales KH, de Vries HF, Cappola AR. Integrated management of type 2 diabetes mellitus and depression treatment to improve medication adherence: a randomized controlled trial. Ann Fam Med 2012; 10: $15-22$.

45. Guldberg TL, Vedsted P, Kristensen JK, Lauritzen T. Improved quality of Type 2 diabetes care following electronic feedback of treatment status to general practitioners: a cluster randomized controlled trial. Diabet Med 2011; 28: 325-32.

46. Nesari M, Zakerimoghadam M, Rajab A, Bassampour S, Faghihzadeh S. Effect of telephone follow-up on adherence to a diabetes therapeutic regimen. Jpn J Nurs Sci 2010; $7:$ 121-8.

47. Odegard PS, Goo A, Hummel J, Williams KL, Gray SL. Caring for poorly controlled diabetes mellitus: a randomized pharmacist intervention. Ann Pharmacother 2005; 39: 433-40.

48. Vervloet M, Dijk L, Santen-Reestman J, Vlijmen B, Wingerden P, Bouvy ML, et al. SMS reminders improve adherence to oral medication in type 2 diabetes patients who are real time electronically monitored. Int J Med Inform 2012; 81: 594604. 
49. Vervloet M, van Dijk L, de Bakker DH, Souverein PC, Santen-Reestman J, van Vlijmen B, et al. Short- and long-term effects of real-time medication monitoring with short message service (SMS) reminders for missed doses on the refill adherence of people with Type 2 diabetes: evidence from a randomized controlled trial. Diabet Med 2014; 31: 821-8.

50. Vervloet M, van Dijk L, Santen-Reestman J, van Vlijmen B, Bouvy ML, de Bakker $\mathrm{DH}$. Improving medication adherence in diabetes type 2 patients through Real Time Medication Monitoring: a Randomised Controlled Trial to evaluate the effect of monitoring patients' medication use combined with short message service (SMS) reminders. BMC Health Serv Res 2011; 11: 5.

51. Wakefield BJ, Holman JE, Ray A, Scherubel M, Adams MR, Hillis SL, et al. Effectiveness of home telehealth in comorbid diabetes and hypertension: a randomized, controlled trial. Telemed J E Health 2011; 17: 254-61.

52. Wakefield BJ, Holman JE, Ray A, Scherubel M, Adams MR, Hills SL, et al. Outcomes of a home telehealth intervention for patients with diabetes and hypertension. Telemed J E Health 2012; 18: 575-9.

53. Fisher L, Hessler D, Glasgow RE, Arean PA, Masharani U, Naranjo D, et al. REDEEM: a pragmatic trial to reduce diabetes distress. Diabetes Care 2013; 36: 2551-8.

54. Glasgow R, Christiansen SM, Kurz D, King DK, Woolley T, Faber AJ, et al. Engagement in a diabetes self-management website: usage patterns and generalizability of program use. J Med Internet Res 2011; 13: e9.

55. Glasgow RE, Kurz D, King D, Dickman JM, Faber AJ, Halterman E, et al. Outcomes of minimal and moderate support versions of an internet-based diabetes self-management support program. J Gen Intern Med 2010; 25: 1315-22. 
56. Glasgow RE, Kurz D, King D, Dickman JM, Faber AJ, Halterman E, et al. Twelve-month outcomes of an Internet-based diabetes self-management support program. Patient Educ Couns 2012; 87: 81-92.

57. Janz NK, Becker MH. The Health Belief Model: A Decade Later. Health Educ Q 1984; 11: 1-47.

58. Bogner HR, de Vries HF. Integration of depression and hypertension treatment: a pilot, randomized controlled trial. Ann Fam Med 2008;6:295-301.

59. Fishbein M, Ajzen I. Belief, attitude, intention and behavior: An introduction to theory and research. Addison-Wesley Pub 1975.

60. Bandura A. Self-efficacy: toward a unifying theory of behavioral change. Psychol Rev 1977; 84: 191-215.

61. Leventhal H, Cameron L. Behavioral theories and the problem of compliance. Patient Educ Couns 1987; 10: 117-38.

62. Garfield S, Clifford S, Eliasson L, Barber N, Willson A. Suitability of measures of self-reported medication adherence for routine clinical use: a systematic review. BMC Med Res Methodol 2011;11:149.

63. Hearnshaw H, Lindenmeyer A, Vermeire E, Van Royen P, Wens J, Biot Y. Interventions to improve adherence to medication in people with type 2 diabetes mellitus: the role of nurses. EDN 2006;3:73-7.

64. Vermeire E, Wens J, Van Royen P, Biot Y, Hearnshaw H, Lindenmeyer A. Interventions for improving adherence to treatment recommendations in people with type 2 diabetes mellitus. Cochrane Database of Systematic Reviews. 2005; 18;CD003638.

65. Fairman K, Matheral B. Evaluating medication adherence: which measure is right for your program? JMPC 2000;6:4. 
66. Vrijens B, De Geest S, Hughes DA, Przemyslaw K, Demonceau J, Ruppar T, et al. A new taxonomy for describing and defining adherence to medications. $\mathrm{Br} \mathrm{J}$ Clin Pharmacol 2012;73:691-705.

67. Farmer KC. Methods for measuring and monitoring medication regimen adherence in clinical trials and clinical practice. Clin Ther 1999;21:1074-90.

68. Craig P, Dieppe P, Macintyre S, Michie S, Nazareth I, Petticrew M.

Developing and evaluating complex interventions: the new Medical Research Council guidance. BMJ 2008; 337: a1655.

69. Michie S, Abraham C. Interventions to change health behaviours: evidencebased or evidence-inspired? Psychology \& Health 2004; 19: 29-49. 
TABLE 1. CHARACTERISTICS OF THE INTERVENTIONS IDENTIFIED IN THE SYSTEMATIC REVIEW

\begin{tabular}{|c|c|c|c|c|c|c|}
\hline Author(s)/Country & Setting & Key elements of intervention & Theoretical model used & $\begin{array}{l}\text { Comparison } \\
\text { Group }\end{array}$ & Design & $\begin{array}{c}\text { Medication } \\
\text { adherence } \\
\text { measure }\end{array}$ \\
\hline \multicolumn{7}{|c|}{ 1. Interventions based on brief messages to improve medication adherence } \\
\hline $\begin{array}{l}\text { Arora et al. } \\
\text { (2013) [41]/ US }\end{array}$ & Hospital & $\begin{array}{l}\text { Two text messages each day over } 6 \\
\text { months containing } \\
\text { educational/motivational content ( } 1 \\
\text { per day), medication reminders ( } 3 \\
\text { per week), healthy living challenges } \\
\text { (2 per week) and diabetes trivia ( } 2 \\
\text { per week). } \\
\text { ( } n=47)\end{array}$ & $\begin{array}{l}\text { "Health Belief Model" } \\
\text { This model uses concepts } \\
\text { of patients' perceptions } \\
\text { of disease, in } \\
\text { combination with their } \\
\text { individual modifying } \\
\text { factors and the cues to } \\
\text { action they receive, to } \\
\text { generate a likelihood of } \\
\text { undertaking a health } \\
\text { behaviour. }\end{array}$ & $\begin{array}{l}\text { Usual care } \\
\qquad(n=45)\end{array}$ & $\begin{array}{l}\text { Open- } \\
\text { label } \\
\text { two-arm } \\
\text { RCT }\end{array}$ & $\begin{array}{l}\text { Morisky } \\
\text { Medication } \\
\text { Adherence Scale } \\
\text { (8 item self- } \\
\text { report) }\end{array}$ \\
\hline $\begin{array}{l}\text { Brath et al. } \\
\text { (2013) [42]/ Austria }\end{array}$ & $\begin{array}{c}\text { Diabetes } \\
\text { outpatient } \\
\text { clinic }\end{array}$ & $\begin{array}{l}\text { Electronic medication blisters and } \\
\text { mobile phone used to automatically } \\
\text { record information about timing and } \\
\text { number of pills taken. SMS } \\
\text { reminders sent when pills were not } \\
\text { taken. } \\
(n=53)\end{array}$ & Not reported & $\begin{array}{c}\text { Standard } \\
\text { medication } \\
\text { blisters and } \\
\text { handwritten } \\
\text { medication intake } \\
\text { diaries } \\
(n=53) \\
\end{array}$ & $\begin{array}{l}\text { Cross- } \\
\text { over trial }\end{array}$ & $\begin{array}{l}\text { Electronic data in } \\
\text { intervention } \\
\text { condition, } \\
\text { returned } \\
\text { medication } \\
\text { blisters for } \\
\text { control }\end{array}$ \\
\hline $\begin{array}{l}\text { Shetty et al., (2011) } \\
\text { [43]/India }\end{array}$ & Not reported & $\begin{array}{l}\text { SMS messages once every } 3 \text { days. } \\
\text { Messages included advice on } \\
\text { nutrition, physical activity, and } \\
\text { healthy living, and reminders to } \\
\text { follow medication prescriptions. } \\
\qquad(n=110)\end{array}$ & Not reported & $\begin{array}{l}\text { Usual care } \\
(n=105)\end{array}$ & $\begin{array}{l}\text { Two-arm } \\
\text { pilot RCT }\end{array}$ & $\begin{array}{l}\text { Questionnaire } \\
\text { and diary }\end{array}$ \\
\hline
\end{tabular}




\begin{tabular}{|l|l|l|l|l|l|l|}
\hline Author(s)/Country & Setting & Key elements of intervention & Theoretical model used & $\begin{array}{c}\text { Comparison } \\
\text { Group }\end{array}$ & $\begin{array}{c}\text { Design } \\
\text { adherence } \\
\text { measure }\end{array}$ \\
\hline
\end{tabular}

\section{Interventions based on monitoring to improve medication adherence}

\begin{tabular}{|c|c|c|c|c|c|c|}
\hline $\begin{array}{l}\text { Bogner et al. } \\
\text { (2012) [44]/ US }\end{array}$ & Primary Care & $\begin{array}{l}\text { Individualised program to monitor } \\
\text { adherence and address factors } \\
\text { contributing to non-adherence (e.g. } \\
\text { depression, medication cost, side } \\
\text { effects). Patients had in-person and } \\
\text { telephone sessions with integrated } \\
\text { care manager who collaborated } \\
\text { with physician. } \\
(n=88)\end{array}$ & $\begin{array}{l}\text { Model proposed by the } \\
\text { authors, based on causes } \\
\text { of medication non- } \\
\text { adherence (including } \\
\text { depression, chronic } \\
\text { medical conditions, } \\
\text { function, cognition, } \\
\text { social support, cost of } \\
\text { medications, side effects, } \\
\text { and past experiences } \\
\text { with medications). This } \\
\text { model was initially based } \\
\text { on the Theory of } \\
\text { Reasoned Action. }\end{array}$ & $\begin{array}{l}\text { Usual care } \\
\qquad(n=92)\end{array}$ & $\begin{array}{l}\text { Two-arm } \\
\text { RCT }\end{array}$ & $\begin{array}{l}\text { Medication } \\
\text { Event } \\
\text { Monitoring } \\
\text { System }\end{array}$ \\
\hline $\begin{array}{l}\text { Guldberg et al., } \\
\text { (2011) [45]/ } \\
\text { Denmark }\end{array}$ & Primary Care & $\begin{array}{l}\text { Electronic feedback system for } \\
\text { general practitioners which } \\
\text { presented data on Type } 2 \text { diabetes } \\
\text { population, allowing data to be used } \\
\text { during individual consultations and } \\
\text { to gain overview of quality of } \\
\text { diabetes care. } \\
(n=1317)\end{array}$ & Not reported & $\begin{array}{l}\text { Usual care } \\
(n=1141)\end{array}$ & $\begin{array}{l}\text { Two-arm } \\
\text { cluster } \\
\text { RCT }\end{array}$ & $\begin{array}{l}\text { Redeemed } \\
\text { prescriptions }\end{array}$ \\
\hline $\begin{array}{l}\text { Nesari et al., (2010) } \\
\text { [46]/ Iran }\end{array}$ & Community & $\begin{array}{l}\text { Sixteen telephone calls by nursing } \\
\text { student over } 12 \text { weeks. Each call } \\
\text { assessed medication taking and } \\
\text { other diabetes care behaviours (e.g. } \\
\text { diet, exercise, foot care). Calls also }\end{array}$ & Not reported & $\begin{array}{l}\text { Usual care } \\
\qquad(n=30)\end{array}$ & $\begin{array}{l}\text { Two-arm } \\
\text { RCT }\end{array}$ & $\begin{array}{l}\text { Self-reported } \\
\text { adherence } \\
\text { questionnaire: } 7 \\
\text { items about } \\
\text { medication } \\
\end{array}$ \\
\hline
\end{tabular}




\begin{tabular}{|c|c|c|c|c|c|c|}
\hline Author(s)/Country & Setting & Key elements of intervention & Theoretical model used & $\begin{array}{l}\text { Comparison } \\
\text { Group }\end{array}$ & Design & $\begin{array}{c}\text { Medication } \\
\text { adherence } \\
\text { measure }\end{array}$ \\
\hline & & $\begin{array}{l}\text { included education and addressing } \\
\text { non-adherence. } \\
(n=30)\end{array}$ & & & & taking \\
\hline $\begin{array}{l}\text { Odegard et al., } \\
\text { (2005) [47]/ US }\end{array}$ & Primary Care & $\begin{array}{l}\text { Pharmacist care plan involving } \\
\text { regular pharmacist-patient and } \\
\text { pharmacist-provider communication } \\
\text { about diabetes care progress. } \\
\qquad(n=30)\end{array}$ & Not reported & $\begin{array}{l}\text { Usual care } \\
\qquad(n=43)\end{array}$ & $\begin{array}{l}\text { Two-arm } \\
\text { multi- } \\
\text { clinic } \\
\text { RCT }\end{array}$ & $\begin{array}{l}\text { Self-reported 2- } \\
\text { question recall } \\
\text { (difficulty } \\
\text { remembering } \\
\text { and missed } \\
\text { doses) }\end{array}$ \\
\hline $\begin{array}{l}\text { Vervloet et al., } \\
(2011,2012,2014) \\
{[31,48-50] /} \\
\text { Netherlands }\end{array}$ & $\begin{array}{l}\text { Community } \\
\text { (pharmacies) }\end{array}$ & $\begin{array}{l}\text { Real time medication monitoring } \\
\text { dispenser (monitoring } \\
\text { component). }(\mathrm{n}=48)\end{array}$ & Not reported & $\begin{array}{l}\text { Usual care } \\
\qquad(n=57)\end{array}$ & $\begin{array}{l}\text { Three- } \\
\text { arm RCT }\end{array}$ & Refill adherence \\
\hline $\begin{array}{l}\text { Wakefield et al., } \\
\text { (2011, 2012) [51, } \\
52] / \text { US }\end{array}$ & Primary Care & $\begin{array}{l}\text { Responded to daily question } \\
\text { (delivered and answered remotely): } \\
\text { "have you taken all your } \\
\text { medications as prescribed" } \\
\text { (monitoring component), and one } \\
\text { other question about diet, exercise, } \\
\text { foot care or side effects. } \\
(n=102)\end{array}$ & Not reported & $\begin{array}{l}\text { Usual care } \\
(n=107)\end{array}$ & $\begin{array}{l}\text { Single- } \\
\text { centre } \\
\text { three- } \\
\text { arm RCT }\end{array}$ & $\begin{array}{l}\text { Self-reported } \\
\text { medication } \\
\text { taking scale } \\
\text { (Morisky et al, } \\
\text { 1986): } 4 \text { items } \\
\text { addressing } \\
\text { medication } \\
\text { taking }\end{array}$ \\
\hline \multicolumn{7}{|c|}{ 3. Interventions combining monitoring and brief messages to improve medication adherence } \\
\hline $\begin{array}{l}\text { Fisher et al., (2013) } \\
\text { [53]/ US }\end{array}$ & Community & $\begin{array}{l}\text { CASM group: Web-based } \\
\text { programme in which participants } \\
\text { selected goals for diabetes self- } \\
\text { management (including adherence) } \\
\text { and monitored progress on the site } \\
\text { (monitoring component). }\end{array}$ & Not reported & $\begin{array}{l}\text { Leap Ahead: } \\
\text { Computer- } \\
\text { delivered diabetes } \\
\text { support and } \\
\text { education. } \\
(n=81) \\
\end{array}$ & $\begin{array}{l}\text { Three- } \\
\text { arm } \\
\text { practical } \\
\text { RCT }\end{array}$ & $\begin{array}{l}\text { Hill-Bone } \\
\text { Compliance } \\
\text { Scale (8 item } \\
\text { self-report) }\end{array}$ \\
\hline
\end{tabular}




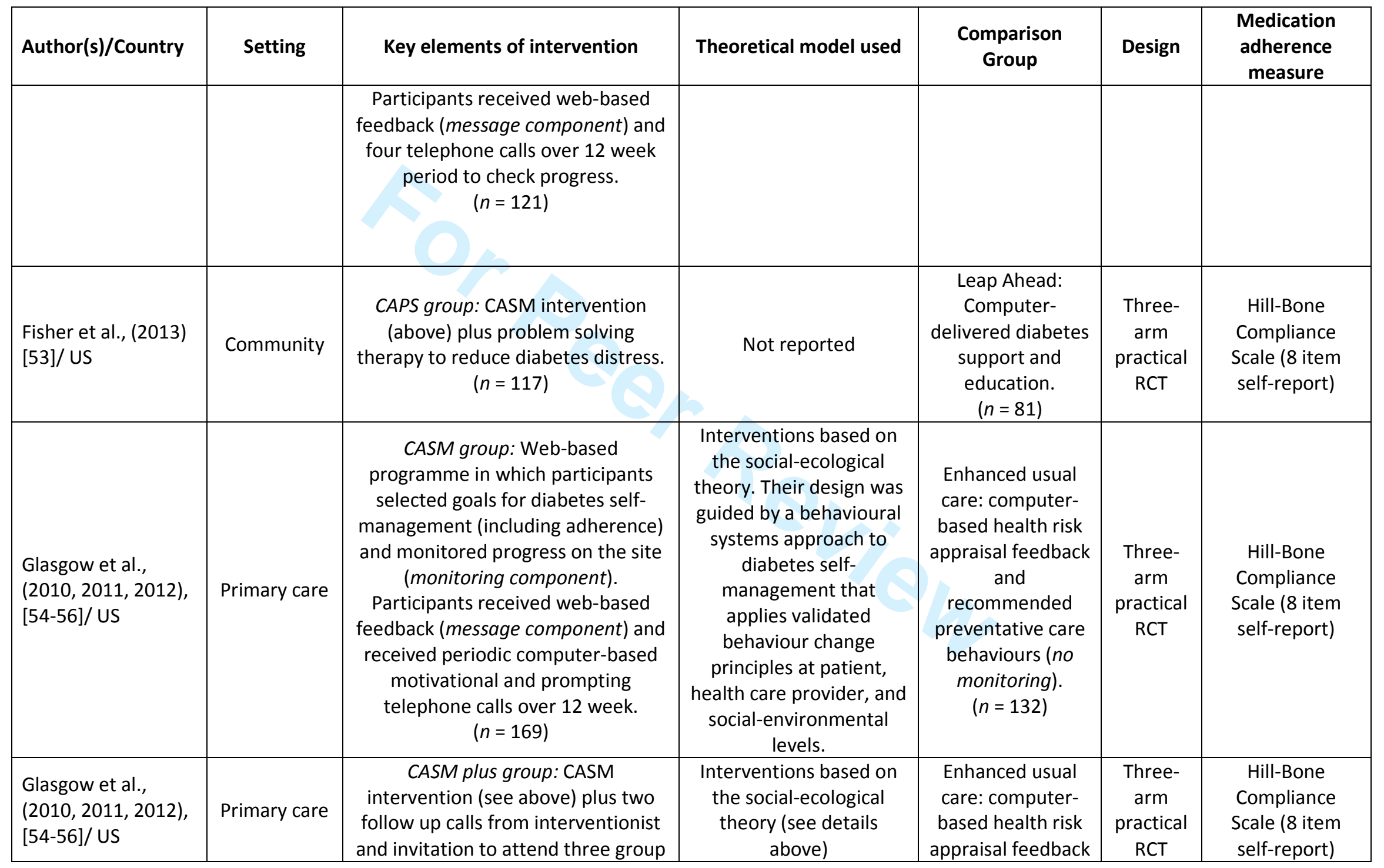




\begin{tabular}{|c|c|c|c|c|c|c|}
\hline Author(s)/Country & Setting & Key elements of intervention & Theoretical model used & $\begin{array}{c}\text { Comparison } \\
\text { Group }\end{array}$ & Design & $\begin{array}{c}\text { Medication } \\
\text { adherence } \\
\text { measure }\end{array}$ \\
\hline & & $\begin{array}{l}\text { sessions about healthy eating, } \\
\text { maintenance, and community } \\
\text { diabetes resources } \\
(n=162)\end{array}$ & & $\begin{array}{c}\text { and } \\
\text { recommended } \\
\text { preventative care } \\
\text { behaviours (no } \\
\text { monitoring). } \\
(n=132)\end{array}$ & & \\
\hline $\begin{array}{l}\text { Wakefield et al., } \\
\text { (2011, 2012) [51, } \\
52] / \text { US }\end{array}$ & Primary Care & $\begin{array}{l}\text { Monitoring component plus } \\
\text { prompts/messages about } \\
\text { medications and other aspects of } \\
\text { disease management (including } \\
\text { behaviour and lifestyle). } \\
\quad(n=107)\end{array}$ & Not reported & $\begin{array}{l}\text { Usual care } \\
(n=107)\end{array}$ & $\begin{array}{c}\text { Single- } \\
\text { centre } \\
\text { three- } \\
\text { arm RCT }\end{array}$ & $\begin{array}{l}\text { Self-reported } \\
\text { medication } \\
\text { taking scale } \\
\text { (Morisky et al, } \\
\text { 1986): } 4 \text { items } \\
\text { addressing } \\
\text { medication } \\
\text { taking }\end{array}$ \\
\hline
\end{tabular}

RCT, randomized controlled trial; $n=$ number of participants. 
TABLE 2. MAIN FINDINGS OF THE IDENTIFIED TRIALS

\begin{tabular}{|c|c|c|}
\hline Author(s) & Impact on medication adherence & Impact on clinical outcomes \\
\hline \multicolumn{3}{|c|}{ 1. Interventions based on brief messages to improve medication adherence } \\
\hline $\begin{array}{l}\text { Arora et al. } \\
\text { (2013) [41] }\end{array}$ & $\begin{array}{l}\text { Average increase of } 0.9 \text { points }(11.3 \%) \text { in patient-reported } \\
\text { medication adherence in the intervention, whereas no } \\
\text { significant differences were observed in the group receiving } \\
\text { usual care. }\end{array}$ & $\begin{array}{l}\text { Improved glycaemic control in the intervention group (higher } \\
\text { reduction in mean HbA1c in the intervention than in the control } \\
\text { group). } \\
\text { After six months } \mathrm{HbA} 1 \mathrm{C} \text { level decreased by } 12 \mathrm{mmol} / \mathrm{mol}(1.1 \%) \text { in the } \\
\text { intervention compared with } 5 \mathrm{mmol} / \mathrm{mol}(0.6 \%) \text { in the control group } \\
{[\Delta=5 \mathrm{mmol} / \mathrm{mol}(0.5 \%) ; 95 \% \mathrm{Cl}-3 \mathrm{mmol} / \mathrm{mol}(-0.3 \%) \text { to } 13 \mathrm{mmol} / \mathrm{mol}} \\
(1.2 \%)] .\end{array}$ \\
\hline $\begin{array}{l}\text { Brath et al. } \\
\text { (2013) [42] }\end{array}$ & $\begin{array}{c}\text { Significantly better adherence to metformin in the intervention } \\
\text { phase of the cross-over trial ( } P=0.04 \text {; effect size not reported), } \\
\text { but no differences observed for the other three medications } \\
\text { examined (Simvastatin, Rosuvastatin and Ramipril). }\end{array}$ & $\begin{array}{l}\text { Statistically significant improvements observed in mean blood pressure } \\
\text { (from } 133 / 75 \text { to } 128 / 70 \mathrm{mmHg} \text { ), and in total and LDL cholesterol } \\
\text { concentrations (166 to } 155 \text {, and } 87 \text { to } 80 \mathrm{mg} \mathrm{dl}^{-1} \text {, respectively) but not } \\
\text { in fasting plasms glucose, } \mathrm{HbA} 1 \mathrm{c} \text {, weight and } \mathrm{HDL} \text { cholesterol. }\end{array}$ \\
\hline $\begin{array}{l}\text { Shetty et al., } \\
\text { (2011) [43] }\end{array}$ & $\begin{array}{l}\text { Unclear reported improvements in medication adherence in } \\
\text { both intervention and control groups (effect sizes and group } \\
\text { comparisons not reported). }\end{array}$ & $\begin{array}{l}\text { The percentage of patients with }<64 \mathrm{mmol} / \mathrm{mol}(<8.0 \%) \text { and without } \\
\text { hypertriglyceridemia increased significantly at the first year in the } \\
\text { intervention group (from } 31 \% \text { to } 55 \% \text { and from } 54 \% \text { to } 76 \%) \text {. } \\
\text { Percentage with high LDL-C decreased significantly in both groups. } \\
\text { There was no significant difference in the percentage of obesity among } \\
\text { the patients in either group. }\end{array}$ \\
\hline \multicolumn{3}{|c|}{ 2. Interventions based on monitoring to improve medication adherence } \\
\hline $\begin{array}{l}\text { Bogner et al. } \\
\text { (2012) [44] }\end{array}$ & $\begin{array}{l}\text { After } 12 \text { weeks in the intervention group increased the } \\
\text { proportion of patients with more than } 80 \% \text { adherence to oral } \\
\text { hypoglycaemic agent (from } 37 \% \text { to } 65 \% ; P<0.001 \text { ) and to } \\
\text { antidepressant medication (from } 30 \% \text { to } 61 \% \text {; } P<0.001 \text { ), } \\
\text { whereas no differences were observed in the control group. }\end{array}$ & $\begin{array}{c}\text { Patients who received the intervention were more likely to glycated } \\
\text { haemoglobin }<53 \mathrm{mmol} / \mathrm{mol}(<7 \%) \text { (intervention } 60.9 \% \text { vs usual care } \\
35.7 \% ; P<0.001 \text { ) and remission of depression ( } \mathrm{PHQ}-9 \text { score }<5 \text { : } \\
\text { intervention } 58.7 \% \text { vs usual care } 30.7 \% ; P<0.001 \text { ) in comparison with } \\
\text { patients in the usual care group at } 12 \text { weeks. }\end{array}$ \\
\hline
\end{tabular}




\begin{tabular}{|c|c|c|}
\hline Author(s) & Impact on medication adherence & Impact on clinical outcomes \\
\hline $\begin{array}{l}\text { Guldberg et al., } \\
\text { (2011) [45] }\end{array}$ & $\begin{array}{l}\text { Patients the intervention group more often redeemed } \\
\text { recommended prescriptions than patients in the control group } \\
\text { (oral antidiabetic treatment, } 32.8 \% \text { vs. } 12.0 \% \text {; insulin } \\
\text { treatment, } 33.8 \% \text { vs. } 12.4 \% \text {; lipid-lowering medication, } 38.3 \text { vs. } \\
\text { 18.6\%; blood pressure medication, } 27.6 \% \text { vs. } 16.3 \% \text {, all } \\
\text { differences being statistically significant). }\end{array}$ & $\begin{array}{l}\text { No differences were observed between the intervention and control } \\
\text { group after the intervention in the two outcome measures included in } \\
\text { the trial (glycated haemoglobin and serum cholesterol). }\end{array}$ \\
\hline $\begin{array}{l}\text { Nesari et al., } \\
\text { (2010) [46] }\end{array}$ & $\begin{array}{l}\text { 8.44\% increase in patient reported medication adherence } \\
\text { score in the intervention group, whereas no statistically } \\
\text { significant differences were observed in the control group. }\end{array}$ & $\begin{array}{l}\text { Significant difference in } \mathrm{HbA1c} \text { between the groups after } 12 \text { weeks } \\
\text { (experimental group: } 53 \mathrm{mmol} / \mathrm{mol}(7.0 \%) ; \text { control group: } 71 \\
\mathrm{mmol} / \mathrm{mol}(8.6 \%) ; P<0.001) .\end{array}$ \\
\hline $\begin{array}{l}\text { Odegard et al., } \\
\text { (2005) [47] }\end{array}$ & $\begin{array}{l}\text { No significant differences between the intervention and } \\
\text { control group were observed in medication adherence. }\end{array}$ & $\begin{array}{c}\text { No differences in } \mathrm{HbA} 1 \mathrm{c} \text { between groups over the } 12 \text {-month period } \\
(P=0.61) \text {. A reduction in } \mathrm{HbA1c} \text { was noted for both groups over time } \\
\text { compared with baseline }(P=0.001) \text {. }\end{array}$ \\
\hline $\begin{array}{l}\text { Vervloet et al., } \\
(2011,2012, \\
2014)[31,48- \\
50]\end{array}$ & $\begin{array}{l}\text { No significant differences between the intervention and } \\
\text { control group were observed in medication adherence. }\end{array}$ & Clinical outcomes not examined \\
\hline $\begin{array}{l}\text { Wakefield et } \\
\text { al., (2011, } \\
\text { 2012) }[51,52] \\
\end{array}$ & $\begin{array}{l}\text { No significant differences between the intervention and } \\
\text { control group were observed in medication adherence. }\end{array}$ & $\begin{array}{l}\text { The low-intensity intervention (including only monitoring but not } \\
\text { message reminders) significantly decreased } \mathrm{HbA1c}(-4 \mathrm{mmol} / \mathrm{mol} \text { (- } \\
0.4 \%), P<0.05) \text {, but not blood pressure. }\end{array}$ \\
\hline \multicolumn{3}{|c|}{ 3. Interventions combining monitoring and brief messages to improve medication adherence } \\
\hline $\begin{array}{l}\text { Fisher et al., } \\
\text { (2013) [53] }\end{array}$ & $\begin{array}{l}\text { CASM group: No significant differences between the CASM and } \\
\text { control group were observed in medication adherence. }\end{array}$ & $\begin{array}{l}\text { CASM group: No significant time or group effects observed for the only } \\
\text { intermediate outcome examined (HbA1c). }\end{array}$ \\
\hline $\begin{array}{l}\text { Fisher et al., } \\
\text { (2013) [53] }\end{array}$ & $\begin{array}{l}\text { CAPS group: Higher improvement in medication adherence } \\
\text { that the CASM and the control group }(P<0.05)\end{array}$ & $\begin{array}{c}\text { CAPS group: No significant time or group effects observed for the only } \\
\text { intermediate outcome examined (HbA1c). }\end{array}$ \\
\hline
\end{tabular}




\begin{tabular}{|c|c|c|}
\hline $\begin{array}{l}\text { Glasgow et al., } \\
\text { (2010, 2011, } \\
\text { 2012), [54-56] }\end{array}$ & $\begin{array}{l}\text { CASM group: No significant differences between the } \\
\text { intervention and control group were observed in medication } \\
\text { adherence. }\end{array}$ & $\begin{array}{l}\text { CASM group: Consistent, modest improvements in all the clinical } \\
\text { outcomes (body mass, HbA1c, lipidemia, blood pressure, } 10 \text { year } \\
\text { coronary heart disease) across the } 12 \text {-month period in the intervention } \\
\text { groups, but between-group differences were not statistically significant } \\
\text { on any of the measures. }\end{array}$ \\
\hline $\begin{array}{l}\text { Glasgow et al., } \\
(2010,2011, \\
2012),[54-56]\end{array}$ & $\begin{array}{l}\text { CASM plus group: No significant differences between the } \\
\text { intervention and control group were observed in medication } \\
\text { adherence. }\end{array}$ & $\begin{array}{l}\text { CASM plus group: Consistent, modest improvements in all the clinical } \\
\text { outcomes (body mass, HbA1c, lipidemia, blood pressure, } 10 \text { year } \\
\text { coronary heart disease) across the } 12 \text {-month period in the intervention } \\
\text { groups, but between-group differences were not statistically significant } \\
\text { on any of the measures. }\end{array}$ \\
\hline $\begin{array}{l}\text { Vervloet et al., } \\
(2011,2012, \\
2014)[31,48- \\
50]\end{array}$ & $\begin{array}{c}\text { After one year medication adherence in the intervention group } \\
\text { was significantly higher than in the control group ( } 79.5 \% \text { vs. } \\
64.5 \% ; P<0.001) \text { and showed a significant improvement from } \\
\text { baseline }(+16.3 \% ; P<0.001) \text {. }\end{array}$ & Clinical outcomes not examined \\
\hline
\end{tabular}

$\mathrm{HbA1c}$, glycated haemoglobin; $\mathrm{mmHg}$, millimetre of mercury; $\Delta$, between group difference; $\mathrm{Cl}$, confidence interval ; LDL-C, low density lipoprotein cholesterol; 
TABLE 3. DEGREE OF USE OF THEORY IN THE DEVELOPMENT OF THE INTERVENTIONS*

\begin{tabular}{|c|c|c|}
\hline Criterion & Description & $\begin{array}{l}\text { Number of trials for which } \\
\text { there is some evidence that } \\
\text { this criterion is satisfied } \\
\qquad(\mathrm{N}=11)\end{array}$ \\
\hline 1. Theory/model of behaviour mentioned & $\begin{array}{l}\text { Models/theories that specify relations among variables, in order to explain } \\
\text { or predict behaviour are mentioned, even if the intervention is not based } \\
\text { on this theory. }\end{array}$ & 4 \\
\hline $\begin{array}{l}\text { 2. Targeted construct mentioned as predictor } \\
\text { of behaviour }\end{array}$ & $\begin{array}{l}\text { Evidence that the 'targeted' construct that the study intervention is } \\
\text { hypothesized to change is presented within the introduction or method }\end{array}$ & 2 \\
\hline 3. Intervention based on single theory & $\begin{array}{l}\text { The intervention is based on a single theory (rather than a combination of } \\
\text { theories or theory predictors). }\end{array}$ & 2 \\
\hline $\begin{array}{l}\text { 4. Theory used to select recipients for the } \\
\text { intervention }\end{array}$ & $\begin{array}{l}\text { Participants were screened/selected based on achieving a particular } \\
\text { score/level on a theory-relevant construct. }\end{array}$ & 0 \\
\hline $\begin{array}{l}\text { 5. Theory used to select/ develop } \\
\text { intervention techniques }\end{array}$ & $\begin{array}{l}\text { The intervention is explicitly based on a theory or combination of theories } \\
\text { and predictors. }\end{array}$ & 4 \\
\hline $\begin{array}{l}\text { 6. Theory used to tailor intervention } \\
\text { techniques to recipients }\end{array}$ & $\begin{array}{l}\text { The intervention differs for different sub-groups that vary on a } \\
\text { psychological construct (e.g., stage of change) at baseline. }\end{array}$ & 0 \\
\hline $\begin{array}{l}\text { 7. All intervention techniques are explicitly } \\
\text { linked to at least one construct }\end{array}$ & $\begin{array}{l}\text { Each intervention technique is explicitly linked to at least one theory- } \\
\text { relevant construct. }\end{array}$ & 1 \\
\hline $\begin{array}{l}\text { 8. At least one, but not all, of the intervention } \\
\text { techniques are explicitly linked to at least } \\
\text { one theory-relevant construct }\end{array}$ & $\begin{array}{l}\text { At least one, but not all, of the intervention techniques are explicitly linked } \\
\text { to at least one theory-relevant construct. }\end{array}$ & 2 \\
\hline $\begin{array}{l}\text { 9. Group of techniques are linked to a group } \\
\text { of constructs }\end{array}$ & A cluster of techniques is linked to a cluster of constructs. & 0 \\
\hline $\begin{array}{l}\text { 10. All theory-relevant constructs are } \\
\text { explicitly linked to at least one } \\
\text { intervention technique }\end{array}$ & $\begin{array}{l}\text { Every theoretical construct within a stated theory (see item } 5 \text { ) is linked to } \\
\text { at least one intervention technique. }\end{array}$ & 1 \\
\hline $\begin{array}{l}\text { 11. At least one, but not all, of the theory } \\
\text { relevant constructs are explicitly linked to }\end{array}$ & $\begin{array}{l}\text { At least one, but not all, of the theoretical constructs within a stated } \\
\text { theory are linked to at least one intervention technique. }\end{array}$ & 2 \\
\hline
\end{tabular}


at least one intervention technique

\begin{tabular}{|c|c|c|}
\hline 12. Theory-relevant constructs are measured & $\begin{array}{l}\text { (a) At least one construct of theory mentioned in relation to the } \\
\text { intervention is measured post-intervention. }\end{array}$ & 1 \\
\hline \multirow[t]{4}{*}{ 13. Quality of measures } & $\begin{array}{l}\text { At least one of the measures of theory relevant constructs had some } \\
\text { evidence for their reliability. }\end{array}$ & 0 \\
\hline & $\begin{array}{l}\text { At least one of the measures of theory relevant constructs have been } \\
\text { previously validated }\end{array}$ & 0 \\
\hline & The behaviour measure had some evidence for its reliability & 3 \\
\hline & The behaviour measure has been previously validated. & 3 \\
\hline \multirow{4}{*}{$\begin{array}{l}\text { 14. Randomization of participants to } \\
\text { condition }\end{array}$} & Do the authors claim randomization? & 4 \\
\hline & $\begin{array}{l}\text { Is a method of random allocation to condition described (e.g., random } \\
\text { number generator; coin toss). }\end{array}$ & 4 \\
\hline & Was the success of randomization tested? & 4 \\
\hline & $\begin{array}{l}\text { Was the randomization successful (or baseline differences between } \\
\text { intervention and control group statistically controlled)? }\end{array}$ & 3 \\
\hline $\begin{array}{l}\text { 15. Changes in measured theory-relevant } \\
\text { constructs }\end{array}$ & $\begin{array}{l}\text { The intervention leads to significant change in at least one theory-relevant } \\
\text { construct/ predictor (vs. control group) in favour of the intervention. }\end{array}$ & 0 \\
\hline 16. Mediational analysis of construct(s) & $\begin{array}{l}\text { Any evidence of hypothesised mediating variable or change in } \\
\text { hypothesised mediating variable predicting dependent variable? }\end{array}$ & 0 \\
\hline 17. Results discussed in relation to theory & Results are discussed in terms of the theoretical basis of the intervention & 0 \\
\hline 18. Appropriate support for theory & $\begin{array}{l}\text { Support for the theory is based on appropriate mediation OR refutation of } \\
\text { the theory is based on obtaining appropriate null effects }\end{array}$ & 0 \\
\hline
\end{tabular}




\section{Page 37 of 63}

Diabetic Medicine

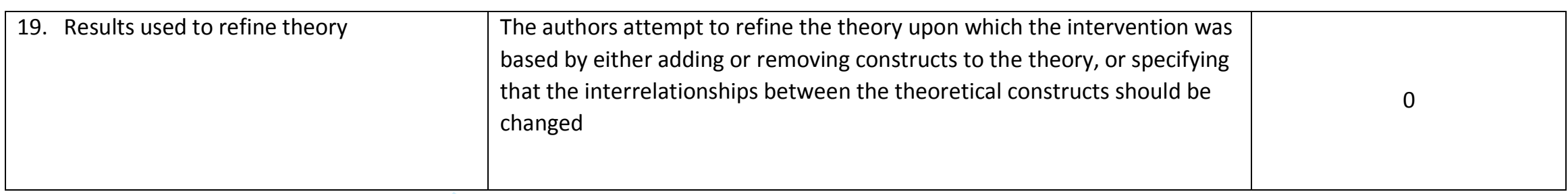

* Extent to which the interventions are theory-based, examined by using the theory coding scheme developed by Michie et al [33].Information reported only for the four trials that reported the use of a theoretical model for the development of the intervention(s) (item $1=$ yes).

DV = dependent variable; IV= independent variable; HBM =Health Belief Model; SCT =Social Cognitive Theory; TPB =Theory of Planned Behaviour 


\section{FIGURE LEGENDS}

Figure 1. Flowchart of articles included at each stage of the screening process

Figure 2. Cochrane summary risk of bias for trials of monitoring of medication use and brief messaging interventions to promote medication adherence for patients with type 2 diabetes $(n=$ 11).

Figure 3. Cochrane individual risk of bias for trials of monitoring of medication use and brief messaging interventions to promote medication adherence for patients with type 2 diabetes $(n=11)$

Figure 4. Standardised mean difference in size of effect of intervention compared with "no treatment" for patient-reported adherence to diabetes medication. SMD, standardized mean difference; $\mathrm{Cl}$, confidence interval; $\mathrm{N}$, number of participants; $\mathrm{SD}$, standard deviation. 


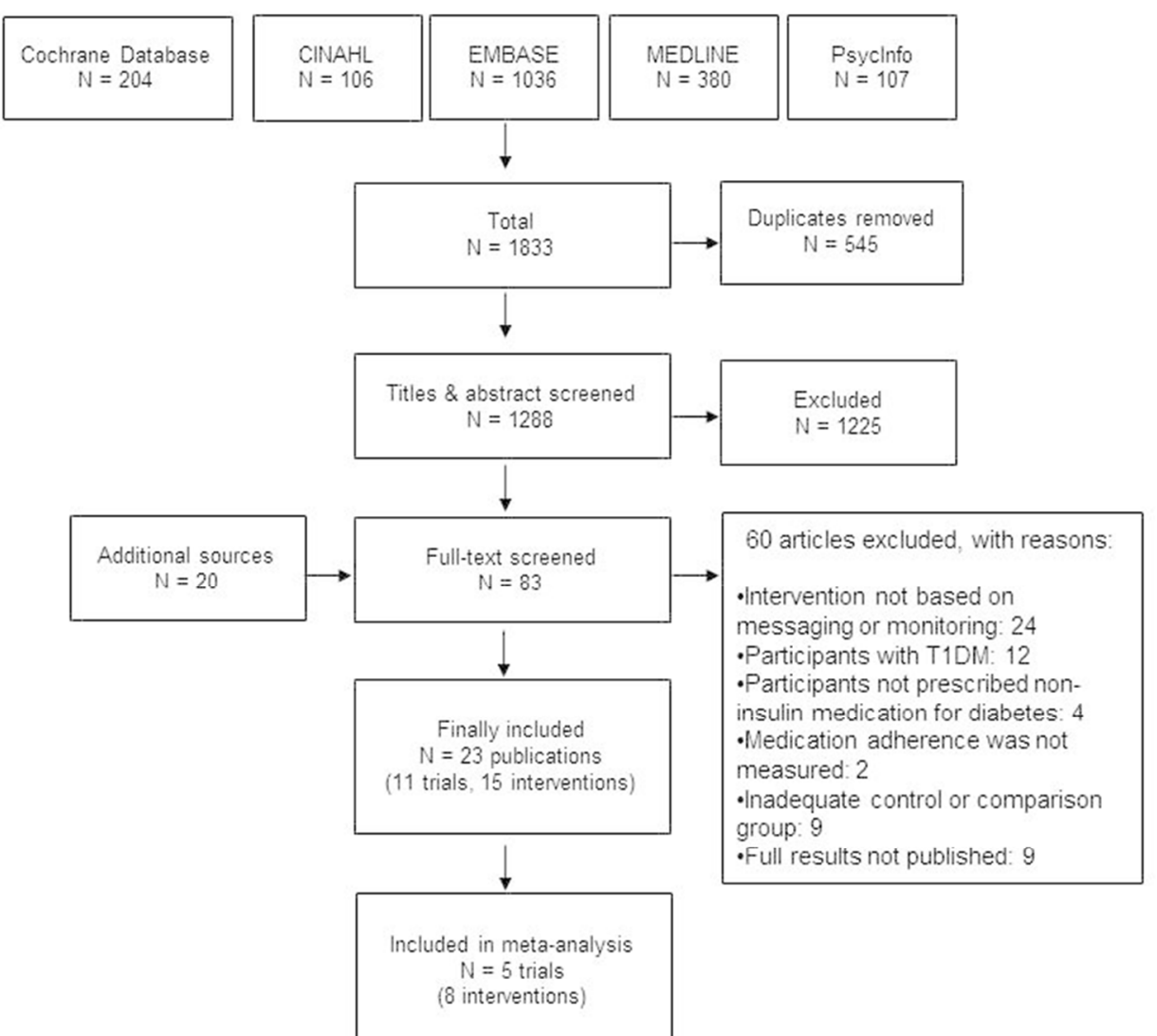

$200 \times 190 \mathrm{~mm}(96 \times 96 \mathrm{DPI})$ 


\section{Page 41 of 63}

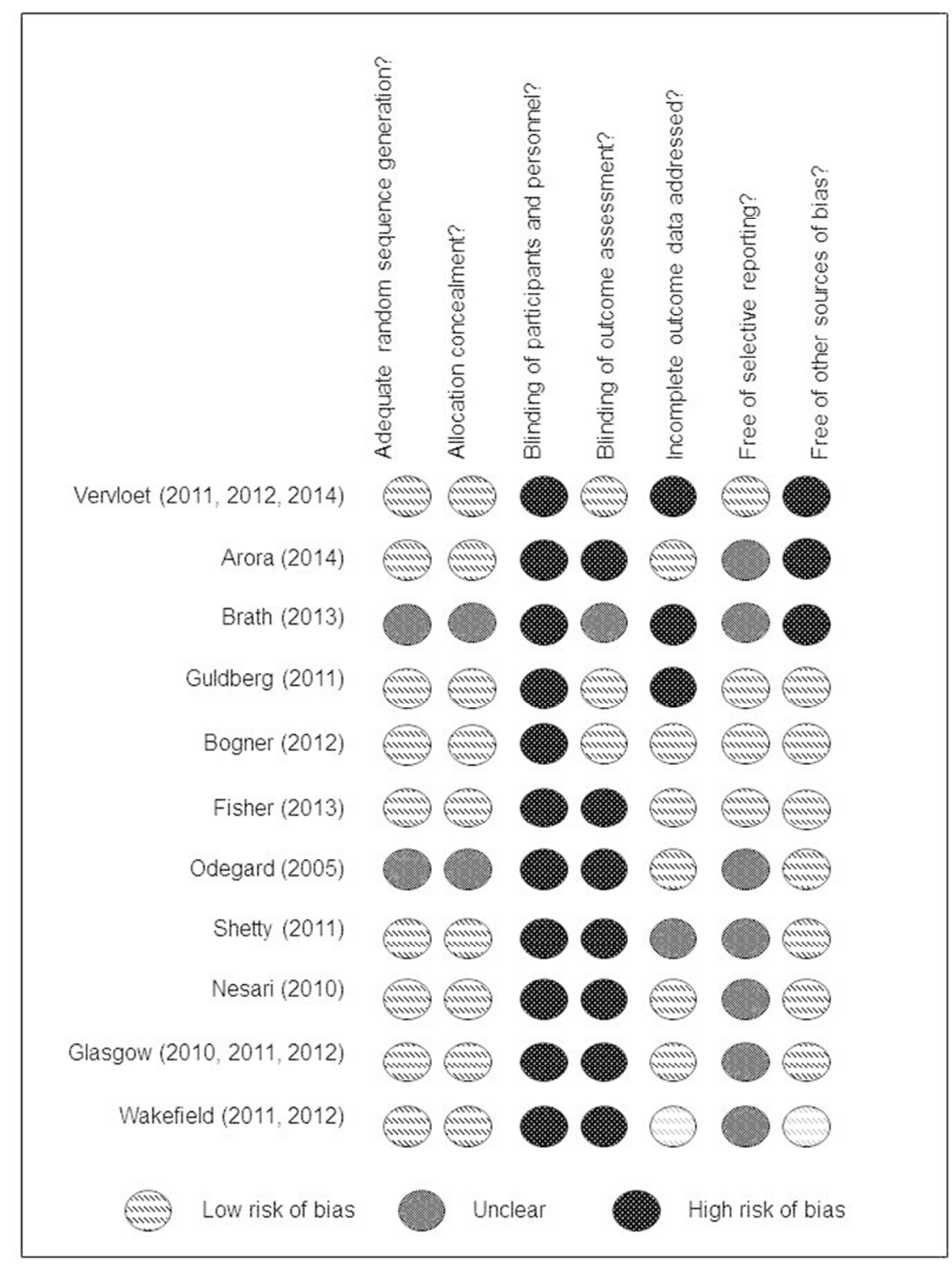

$190 \times 254 \mathrm{~mm}(96 \times 96 \mathrm{DPI})$ 
$\mathrm{N}$, mean $\quad \mathrm{N}$, mean $\quad \%$ size $(95 \% \mathrm{CI}) \quad(\mathrm{SD})$; Treatment $\quad(\mathrm{SD})$; Control Weight

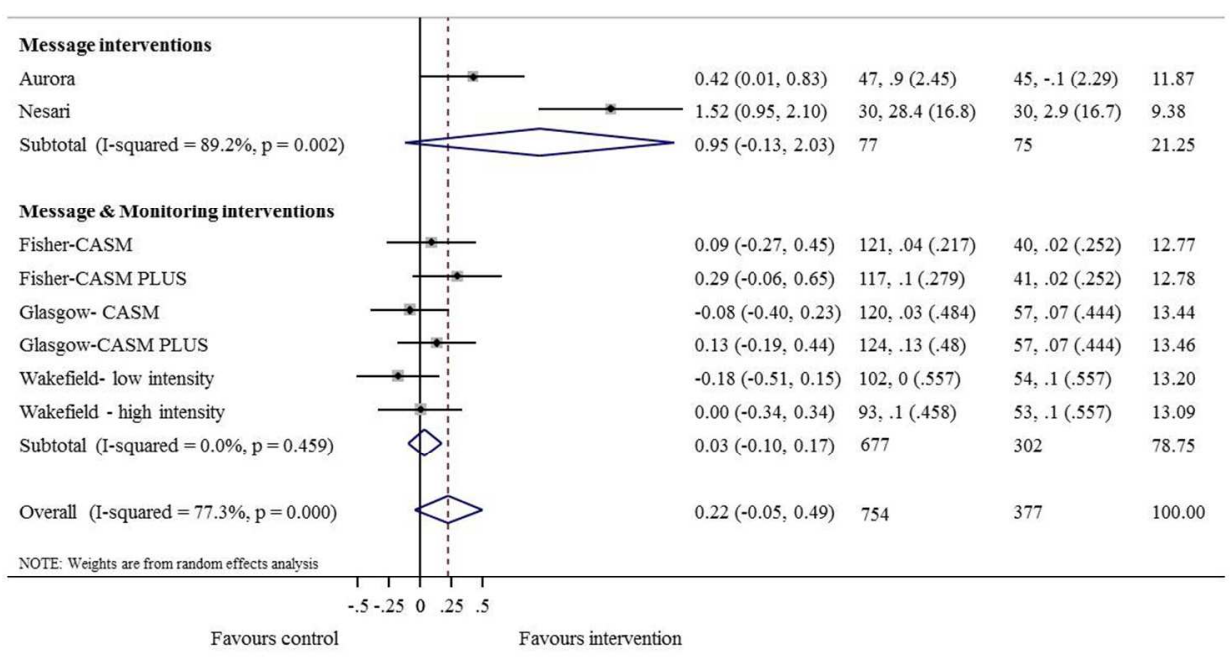

$319 \times 209 \mathrm{~mm}(96 \times 96 \mathrm{DPI})$ 


\section{ONLINE APPENDIX 1. BIBLIOGRAPHIC SEARCHES}

\section{a. Details of search strategy}

\begin{tabular}{|c|c|c|}
\hline Diabetes & Medication Adherence & Trials \\
\hline $\begin{array}{l}\text { \#1. Diabetes mellitus, non insulin } \\
\text { dependent.mp. or exp non } \\
\text { insulin dependent diabetes } \\
\text { mellitus/ } \\
\text { [mp=title, abstract, subject } \\
\text { headings, heading word, drug } \\
\text { trade name, original title, } \\
\text { device manufacturer, drug } \\
\text { manufacturer, device trade } \\
\text { name, keyword] } \\
\text { \#2 niddm.mp. } \\
\text { \#3 diabet* and (non insulin* } \\
\text { depend* or noninsulin* } \\
\text { depend* or } \\
\text { noninsulindepend* or non } \\
\text { insulindepend* or } \\
\text { noninsulinsdepend* or non } \\
\text { insulinsdepend*).mp. } \\
\text { \#4 (typ* } 2 \text { or typ* II) adj } \\
\text { diabet*.mp } \\
\text { \#5 (adult* or matur* or late or } \\
\text { slow or stabl*) adj } \\
\text { diabet*.mp. } \\
\text { \#6 \#1 or \#2 or \#3 or \#4 or \#5 } \\
\text { \#7 exp Diabetes insipidus/ } \\
\text { \#8 \#6 not \#7 } \\
\text { Based on Welschen, } \\
\text { Bloemendal, Nijpels, Dekker, } \\
\text { Heine, Stalman and Bouter [1] }\end{array}$ & $\begin{array}{l}\text { (drug* }^{*} \text { or medicat* or } \\
\text { treatment* or regimen* }^{*} \\
\text { or pill*) adj2 (adherence } \\
\text { or non-adherence or } \\
\text { nonadherence or } \\
\text { compliance or non- } \\
\text { compliance or } \\
\text { noncompliance or } \\
\text { taking) }\end{array}$ & $\begin{array}{l}\text { \#1: random*.mp. } \\
\text { \#2: trial.mp. } \\
\text { \#3: groups.mp. } \\
\text { \#4: blind*.mp. } \\
\text { \#5: mask }{ }^{*} . m p . \\
\text { \#6: intervention*.mp. } \\
\text { \#7: \#1 or \#2 or \#3 or } \\
\quad \# 4 \text { or \#5 or \#6 }\end{array}$ \\
\hline
\end{tabular}




\section{b. Details of electronic database searches}

Ovid MEDLINE(R) 1946 to November Week 3 2014. (final search executed on 16 December 2014)

\begin{tabular}{|c|c|c|}
\hline Searches & Results & Search Type \\
\hline 1 & $\begin{array}{l}\text { Diabetes mellitus, non insulin dependent.mp. or exp } \\
\text { non insulin dependent diabetes mellitus/ }\end{array}$ & 91905 \\
\hline 2 & niddm.mp. & 6850 \\
\hline 3 & $\begin{array}{l}\text { (diabet* and (non insulin* depend* or noninsulin* } \\
\text { depend }^{*} \text { or noninsulindepend } \\
\text { noninsulinsdepend }{ }^{*} \text { )).mp. }\end{array}$ & 11963 \\
\hline 4 & $\left(\left(\right.\right.$ typ $^{*} 2$ or typ ${ }^{*}$ II) adj diabet $\left.{ }^{*}\right) \cdot m p$. & 76047 \\
\hline 5 & $\begin{array}{l}\left(\left(\text { adult }^{*} \text { or matur }\right.\right. \\
\left.\text { diabet }^{*}\right) \cdot \mathrm{mp} \text {. }\end{array}$ & 1262 \\
\hline 6 & 1 or 2 or 3 or 4 or 5 & 116601 \\
\hline 7 & exp diabetes insipidus/ & 7173 \\
\hline 8 & 6 not 7 & 116572 \\
\hline 9 & $\begin{array}{l}\left(\left(\text { drug }^{*} \text { or medicat* or treatment* or regimen* or pill*) }\right.\right. \\
\text { adj2 (adherence or non-adherence or nonadherence or } \\
\text { compliance or non-compliance or noncompliance or } \\
\text { taking)).mp. }\end{array}$ & 33569 \\
\hline 10 & $\begin{array}{l}\text { (random* or trial or groups or blind or mask or } \\
\text { intervention).mp. }\end{array}$ & 2679678 \\
\hline 11 & 8 and 9 and 10 & 446 \\
\hline 12 & $\begin{array}{l}\text { limit } 11 \text { to (english language and humans and yr="1990 } \\
\text {-Current") }\end{array}$ & 417 \\
\hline 13 & $\begin{array}{l}\text { limit } 12 \text { to ("all infant (birth to } 23 \text { months)" or "all child (0 } \\
\text { to } 18 \text { years)") }\end{array}$ & 37 \\
\hline 14 & 12 not 13 & 380 \\
\hline
\end{tabular}




\section{EMBASE 1988 to 2014 Week 50 (final search executed on 16 December 2014)}

\begin{tabular}{|c|c|c|}
\hline 1 & $\begin{array}{l}\text { Diabetes mellitus, non insulin dependent.mp. or exp non } \\
\text { insulin dependent diabetes mellitus/ }\end{array}$ & 149616 \\
\hline 2 & niddm.mp. & 7976 \\
\hline 3 & $\begin{array}{l}\text { (diabet* and (non insulin* depend* or noninsulin* }{ }^{*} \text { depend }^{*} \text { or } \\
\text { noninsulindepend* or non insulindepend* or } \\
\left.\text { noninsulinsdepend }{ }^{*}\right) \text { ).mp. }\end{array}$ & 152929 \\
\hline 4 & $\left(\left(\text { typ }^{*} 2 \text { or typ }^{*} \text { II) adj diabet }\right)^{*}\right) \cdot m p$ & 120702 \\
\hline 5 & ((adult* or matur* or late or slow or stabl*) adj diabet* ${ }^{*} . \mathrm{mp}$. & 129143 \\
\hline 6 & 1 or 2 or 3 or 4 or 5 & 288352 \\
\hline 7 & exp diabetes insipidus/ & 11328 \\
\hline 8 & 6 not 7 & 285494 \\
\hline 9 & $\begin{array}{l}\left.\text { ((drug* or medicat* or treatment* or regimen* or pill* }{ }^{\star}\right) \text { adj2 } \\
\text { (adherence or non-adherence or nonadherence or } \\
\text { compliance or non-compliance or noncompliance or } \\
\text { taking)).mp. }\end{array}$ & 47612 \\
\hline 10 & $\begin{array}{l}\text { (random* or trial or groups or blind or mask or } \\
\text { intervention).mp. }\end{array}$ & 3681587 \\
\hline 11 & 8 and 9 and 10 & 1229 \\
\hline 12 & limit 11 to human & 1166 \\
\hline 13 & limit 12 to english language & 1112 \\
\hline 14 & limit 13 to $y r=" 1990$-Current" & 1103 \\
\hline 15 & $\begin{array}{l}\text { limit } 14 \text { to (embryo }<\text { first trimester }>\text { or infant }<\text { to one year }>\text { or } \\
\text { child }<\text { unspecified age }>\text { or preschool child }<1 \text { to } 6 \text { years }>\text { or } \\
\text { school child }<7 \text { to } 12 \text { years }>\text { or adolescent }<13 \text { to } 17 \text { years }>\text { ) }\end{array}$ & 67 \\
\hline 16 & 14 not 15 & 1036 \\
\hline
\end{tabular}




\section{PsycINFO 1987 to December Week 12014 (final search executed on 16} December 2014)

\begin{tabular}{|c|c|c|}
\hline 1 & non insulin dependent diabetes mellitus.mp. & 136 \\
\hline 2 & NIDDM.mp. & 93 \\
\hline 3 & $\begin{array}{l}\text { (diabet }{ }^{*} \text { and (non insulin* depend* }{ }^{*} \text { or noninsulin* }{ }^{*} \text { depend* or } \\
\text { noninsulindepend }{ }^{*} \text { or non insulindepend* or noninsulinsdepend*)).mp. }\end{array}$ & 257 \\
\hline 4 & $\left(\left(\right.\right.$ typ $^{*} 2$ or typ* II) adj diabet* $) \cdot m p$ & 4438 \\
\hline 5 & $\left(\left(\right.\right.$ adult $^{*}$ or matur* or late or slow or stabl* $)$ adj diabet $\left.{ }^{*}\right) . \mathrm{mp}$. & 75 \\
\hline 6 & 1 or 2 or 3 or 4 or 5 & 4725 \\
\hline 7 & exp diabetes insipidus/ & 85 \\
\hline 8 & 20 & 4708 \\
\hline 9 & $\begin{array}{l}\left(\left(\text { drug }^{*} \text { or medicat* } \text { or treatment }^{*} \text { or regimen* or pill* }{ }^{*} \text { adj2 (adherence }\right.\right. \\
\text { or non-adherence or nonadherence or compliance or non-compliance } \\
\text { or noncompliance or taking })) . \mathrm{mp} \text {. }\end{array}$ & 18434 \\
\hline 10 & (random* or trial or groups or blind or mask or intervention).mp. & 566988 \\
\hline 11 & 8 and 9 and 10 & 116 \\
\hline 12 & limit 11 to (human and english language and yr="1990 -Current") & 111 \\
\hline 13 & $\begin{array}{l}\text { limit } 12 \text { to (childhood <birth to } 12 \text { years }>\text { or adolescence }<13 \text { to } 17 \\
\text { years }>\text { ) }\end{array}$ & 4 \\
\hline 14 & 12 not 13 & 107 \\
\hline
\end{tabular}


CINAHL(final search executed on 16 December 2014)

\begin{tabular}{|c|c|c|}
\hline 1 & non insulin dependent diabetes mellitus & 175 \\
\hline 2 & NIDDM & 306 \\
\hline 3 & $\begin{array}{l}\text { diabet* and (non insulin* depend }^{*} \text { or noninsulin* depend* } \\
\text { or noninsulindepend* or non insulindepend* or } \\
\text { noninsulinsdepend*) }\end{array}$ & 265 \\
\hline 4 & (typ* 2 or typ* II) N1 diabet* & $9,288)$ \\
\hline 5 & (adult* or matur* or late or slow or stabl*) n1 diabet* & 715 \\
\hline 6 & 1 OR 2 OR 3 OR 4 OR 5 & 9,775 \\
\hline 7 & Diabetes Insipidus & 23 \\
\hline 8 & 6 not 7 & 9,774 \\
\hline 9 & $\begin{array}{l}\text { (drug* }^{*} \text { or medicat* or treatment* or regimen* or pill*) N2 } \\
\text { (adherence or non-adherence or nonadherence or } \\
\text { compliance or non-compliance or noncompliance or } \\
\text { taking) }\end{array}$ & 5,275 \\
\hline 10 & $\begin{array}{l}\text { random* or trial or groups or blind or mask or } \\
\text { intervention }\end{array}$ & 154,674 \\
\hline 11 & 8 AND 9 AND 10 & 106 \\
\hline
\end{tabular}

Limiters - Published Date: 19900101-20141231; Human; Language: English; Age Groups: All Adult 
Cochrane Central Register of Controlled Trials Search-Issue 12 of 12, 17 December 2014

\begin{tabular}{|l|l|l|}
\hline Searches & \multicolumn{1}{|c|}{ Results } & \multicolumn{1}{|c|}{$\begin{array}{c}\text { Search } \\
\text { Type }\end{array}$} \\
\hline 1 & Diabetes :TI,AB,KY & 246 \\
\hline 2 & Medication:TI,AB,KY & 26525 \\
\hline 3 & Adherence:TI,AB,KY & 7563 \\
\hline 4 & 2 AND 3 AND 4 & 204 \\
\hline
\end{tabular}




\section{REFERENCES}

1. Welschen LM, Bloemendal E, Nijpels G, Dekker JM, Heine RJ, Stalman WA, et al. Self-monitoring of blood glucose in patients with type 2 diabetes mellitus who are not using insulin. Cochrane Database Syst Rev 2012 18; 1: CD005060.

2. Haynes RB, Ackloo E, Sahota N, McDonald HP, Yao X. Interventions for enhancing medication adherence. Cochrane Database Syst Rev 2008; 16(2): CD000011

3. Higgins JPT, Green S. Cochrane Handbook for Systematic Reviews of Interventions: The Cochrane Collaboration; 2011. Available from: www.cochrane-handbook.org. Last accessed 27 May 2015.

4. Olander EK, Fletcher H, Williams S, Atkinson L, Turner A, French DP. What are the most effective techniques in changing obese individuals' physical activity self-efficacy and behaviour: a systematic review and meta-analysis. Int J Behav Nutr Phys Act 2013; 10: 29. 
ONLINE APPENDIX 2. LIST OF THE DIFFERENT METHODS USED TO MEASURE MEDICATION ADHERENCE

\begin{tabular}{|c|c|c|c|c|}
\hline $\begin{array}{l}\text { Adherence } \\
\text { measure used }\end{array}$ & Format/characteristic of measure & Validity & Reliability & $\begin{array}{l}\text { Trials } \\
\text { using } \\
\text { measure }\end{array}$ \\
\hline \multicolumn{5}{|c|}{ Based on patient-reported information } \\
\hline $\begin{array}{l}\text { Morisky } \\
\text { Medication } \\
\text { Adherence } \\
\text { Scale[1] }\end{array}$ & $\begin{array}{l}8 \text { item self-report. Response categories are } \\
\text { yes/no for each item with a dichotomous response } \\
\text { and a 5-point Likert response for the last item. }\end{array}$ & $\begin{array}{l}\text { [Adapted from Pérez-Escamilla et } \\
\text { al [2]] } \\
\text { Construct validity (confirmatory } \\
\text { factor analysis): one factor. } \\
\text { Concurrent validity: questionnaire } \\
\text { vs MGL r=0.64, P<0.05 } \\
\text { - } S=93.00 \% \\
\text { - } S P=53.00 \% \\
\text { Predictive validity: questionnaire } \\
\text { vs: } \\
\text { - BP control (P<0.05) } \\
\text { - knowledge, attitude, social } \\
\text { support, stress coping, } \\
\text { medication complexity, and } \\
\text { patient satisfaction with }\end{array}$ & $\begin{array}{l}\text { [Adapted from } \\
\text { Pérez-Escamilla } \\
\text { et al [2]] } \\
\text { Internal } \\
\text { consistency: } \\
\text { Cronbach } \alpha= \\
0.83 \text { ); item-total } \\
\text { correlations = } \\
0.30-0.59 \\
\text { Test-retest: not } \\
\text { examined }\end{array}$ & $\begin{array}{l}\text { Arora et al } \\
{[3]}\end{array}$ \\
\hline
\end{tabular}




\begin{tabular}{|c|c|c|c|c|}
\hline & & $\begin{array}{l}\text { clinic visits ( } P<0.05 \text { for all, } \\
\text { except for attitude). }\end{array}$ & & \\
\hline $\begin{array}{l}\text { Hill-Bone } \\
\text { Compliance } \\
\text { Scale [4] }\end{array}$ & $\begin{array}{l}8 \text { item self-report of how often and why medication } \\
\text { is missed on a 4-point Likert scale. }\end{array}$ & $\begin{array}{l}\text { Construct validity (factor analysis): } \\
\text { two factors. }\end{array}$ & $\begin{array}{l}\text { Internal } \\
\text { consistency: } \\
\text { Cronbach } \alpha= \\
0.68) . \\
\text { Test-retest: not } \\
\text { examined }\end{array}$ & $\begin{array}{l}\text { Fisher et al } \\
\text { [5] and } \\
\text { Glasgow et } \\
\text { al [6-8] }\end{array}$ \\
\hline $\begin{array}{l}\text { Edwards } \\
\text { Regimen } \\
\text { Adherence Scale } \\
\text { [9] }\end{array}$ & $\begin{array}{l}6 \text { item self-report measured on 5-point Likert } \\
\text { scale. }\end{array}$ & Unclear & Unclear & $\begin{array}{l}\text { Wakefield et } \\
\text { al }[10,11]\end{array}$ \\
\hline
\end{tabular}




\begin{tabular}{|c|c|c|c|c|}
\hline & & $\begin{array}{l}\text { - Medication intake vs BP } \\
\text { control: } \\
\begin{aligned} \circ & \mathrm{R}^{2}=0.33, \mathrm{P}<0.01 \\
\circ & \mathrm{S}=81.00 \% \\
\circ & \mathrm{SP}=44.00 \% \\
\circ & \mathrm{PPV}=75.00 \% \\
\circ & \mathrm{NPV}=52.00 \%\end{aligned}\end{array}$ & & \\
\hline $\begin{array}{l}\text { Self-reported } \\
\text { questionnaire } \\
\text { developed ad hoc } \\
\text { by researchers }\end{array}$ & $\begin{array}{l}68 \text { items in total ( } 7 \text { items specifically covering } \\
\text { medication adherence). Answered on a } 5 \text { point } \\
\text { Likert scale. Total score for medication adherence } \\
\text { was sum of the } 7 \text { items expressed out of } 100 .\end{array}$ & $\begin{array}{l}\text { Face validity: content of the } \\
\text { questionnaire verified by an } \\
\text { endocrinologist, a dietician, and } \\
\text { eight nurses who had a Master's } \\
\text { degree or PhD }\end{array}$ & $\begin{array}{l}\text { Test-retest } \\
\text { Pearson's } \\
\text { correlation } \\
\text { coefficient }=0.9\end{array}$ & $\begin{array}{l}\text { Nesari et al } \\
{[13]}\end{array}$ \\
\hline $\begin{array}{l}\text { Question about } \\
\text { use of medication }\end{array}$ & $\begin{array}{l}\text { "Are you taking your medications as prescribed?" } \\
\text { Adherence scores represent the proportion of } \\
\text { medications for which the responses agreed with } \\
\text { the directions for use on the VA Pharmacy }\end{array}$ & Unclear & Unclear & $\begin{array}{l}\text { Wakefield et } \\
\text { al }[10,11]\end{array}$ \\
\hline
\end{tabular}




\begin{tabular}{|l|l|l|l|}
\hline & medication profile. & & \\
\hline Daily diary & $\begin{array}{l}\text { Patients were requested to maintain a diary to } \\
\text { note the deviations in physical activity, diet or drug } \\
\text { per week which was quantified at the clinic visits. }\end{array}$ & Unclear & Unclear \\
{$\left[\begin{array}{l}\text { Based on electron } \\
\hline\end{array}\right.$}
\end{tabular}

\section{Based on electronic monitoring}

\begin{tabular}{|c|c|c|c|c|}
\hline $\begin{array}{l}\text { Electronic blister } \\
\text { data }\end{array}$ & $\begin{array}{l}\text { Electronic medication blisters were used as add- } \\
\text { ons to standard medication blisters. Medication } \\
\text { intake rate (doses taken divided by prescribed } \\
\text { doses) was then measured. }\end{array}$ & \multirow{2}{*}{$\begin{array}{l}\text { Face validity: This method is } \\
\text { based on the pill removal, but does } \\
\text { not measure whether or not the } \\
\text { participants actually take the } \\
\text { medication. }\end{array}$} & \multirow[t]{2}{*}{ Highly reliable } & $\begin{array}{l}\text { Brath et al } \\
{[16]}\end{array}$ \\
\hline $\begin{array}{l}\text { Real Time } \\
\text { Medication } \\
\text { Monitoring }\end{array}$ & $\begin{array}{l}\text { Based on an electronic medication dispenser } \\
\text { which monitors patients' medication use, } \\
\text { registering this data in real time at a central } \\
\text { server. The following measures were used: a) } \\
\text { doses taken divided by prescribed doses; b) } \\
\text { doses taken within correct time interval divided by } \\
\text { number of prescribed doses. }\end{array}$ & & & $\begin{array}{l}\text { Vervloet et } \\
\text { al [17-20] }\end{array}$ \\
\hline
\end{tabular}




\begin{tabular}{|c|c|c|c|c|}
\hline & $\begin{array}{l}\text { by the number of doses prescribed during the } \\
\text { observation period. Adherence was dichotomized } \\
\text { at a threshold of } 80 \% \text {. }\end{array}$ & & & \\
\hline $\begin{array}{l}\text { Pharmacy refill } \\
\text { data }\end{array}$ & $\begin{array}{l}\text { Number of days dispensed divided by days on } \\
\text { study period. }\end{array}$ & \multirow[b]{2}{*}{$\begin{array}{l}\text { Face validity: This method is } \\
\text { based on refilling medication, but } \\
\text { does not measure whether or not } \\
\text { the participants actually take the } \\
\text { medication. } \\
\text { Concurrent validity [Adapted from } \\
\text { Steiner et al [22]]: } \\
\text { - Refill compliance correlate } \\
\text { significantly with other } \\
\text { compliance behaviours (such as } \\
\text { appointment-keeping or } \\
\text { medication consumption) in most } \\
\text { studies. } \\
\text { - Studies also found moderate } \\
\text { correlations between refill } \\
\text { compliance measures and serum } \\
\text { drug levels or drug effects such }\end{array}$} & \multirow[t]{2}{*}{ Unclear } & $\begin{array}{l}\text { Vervloet et } \\
\text { al [19] }\end{array}$ \\
\hline $\begin{array}{l}\text { Redeemed } \\
\text { prescriptions }\end{array}$ & $\begin{array}{l}\text { Calculated as percentage of patients who } \\
\text { redeemed prescriptions during } 15 \text { months } \\
\text { following introduction of a feedback system. }\end{array}$ & & & $\begin{array}{l}\text { Guldberg et } \\
\text { al [23] }\end{array}$ \\
\hline
\end{tabular}




\section{Page 55 of 63}

Diabetic Medicine

\begin{tabular}{|l|l|l|l|}
\hline & & $\begin{array}{l}\text { as blood pressure control } \\
\text { - Specific but insensitive measure } \\
\text { of partial compliance as } \\
\text { assessed by other means }\end{array}$ & \\
& & & \\
\hline
\end{tabular}

MGL, Morisky-Green-Levine (scale); PPV, positive predictive value; S, sensitivity; SBP, systolic blood pressure; SP, specificity 


\section{REFERENCES}

1. Morisky DE, Ang A, Krousel-Wood M, Ward HJ. Predictive Validity of a Medication Adherence Measure in an Outpatient Setting. J Clin Hypertens (Greenwich) 2008; 10: 348-54.

2. Perez-Escamilla B, Franco-Trigo L, Moullin JC, Martinez-Martinez F, Garcia-Corpas JP. Identification of validated questionnaires to measure adherence to pharmacological antihypertensive treatments. Patient Prefer Adherence. 2015;9:569578.

3. Arora S, Peters AL, Burner E, Lam CN, Menchine M. Trial to examine text messagebased mHealth in emergency department patients with diabetes (TExT-MED): a randomized controlled trial. Ann Emerg Med 2014; 63: 745-54.

4. Krousel-Wood M, Muntner P, Jannu A, Desalvo K, Re RN. Reliability of a Medication Adherence Measure in an Outpatient Setting. Am J Med Sci 2005; 330: 128-33.

5. Fisher L, Hessler D, Glasgow RE, Arean PA, Masharani U, Naranjo D, et al. REDEEM: a pragmatic trial to reduce diabetes distress. Diabetes Care 2013; 36: 2551-8.

6. Glasgow R, Christiansen SM, Kurz D, King DK, Woolley T, Faber AJ, et al. Engagement in a diabetes self-management website: usage patterns and generalizability of program use. J Med Internet Res 2011; 13: e9.

7. Glasgow RE, Kurz D, King D, Dickman JM, Faber AJ, Halterman E, et al. Outcomes of minimal and moderate support versions of an internet-based diabetes selfmanagement support program. J Gen Intern Med 2010; 25: 1315-22.

8. Glasgow RE, Kurz D, King D, Dickman JM, Faber AJ, Halterman E, et al. Twelvemonth outcomes of an Internet-based diabetes self-management support program. Patient Educ Couns 2012; 87: 81-92.

9. D E. Psychological factors affecting adherence to metabolic control in diabetes mellitus. lowa: University of lowa; 1998.

10. Wakefield BJ, Holman JE, Ray A, Scherubel M, Adams MR, Hillis SL, et al. Effectiveness of home telehealth in comorbid diabetes and hypertension: a randomized, controlled trial. Telemed J E Health 2011; 17: 254-61.

11. Wakefield BJ, Holman JE, Ray A, Scherubel M, Adams MR, Hills SL, et al. Outcomes of a home telehealth intervention for patients with diabetes and hypertension. Telemed J E Health 2012; 18: 575-9.

12. Morisky DE, Green LW, Levine DM. Concurrent and predictive validity of a selfreported measure of medication adherence. Med Care 1986; 24: 67-74. 
13. Nesari M, Zakerimoghadam M, Rajab A, Bassampour S, Faghihzadeh S. Effect of telephone follow-up on adherence to a diabetes therapeutic regimen. Jpn J Nurs Sci 2010; $7:$ : 121-8.

14. Odegard PS, Goo A, Hummel J, Williams KL, Gray SL. Caring for poorly controlled diabetes mellitus: a randomized pharmacist intervention. Ann Pharmacother 2005; 39: 433-40.

15. Shetty AS, Chamukuttan S, Nanditha A, Raj RK, Ramachandran A. Reinforcement of adherence to prescription recommendations in Asian Indian diabetes patients using short message service (SMS): a pilot study. J Assoc Physicians India 2011;59:711-4.

16. Brath H, Morak J, Kastenbauer T, Modre-Osprian R, Strohner-Kastenbauer H, Schwarz M, et al. Mobile health (mHealth) based medication adherence measurement: a pilot trial using electronic blisters in diabetes patients. Br J Clin Pharmacol 2013; 76: 47-55.

17. Vervloet M, Dijk L, Santen-Reestman J, Vlijmen B, Wingerden P, Bouvy ML, et al. SMS reminders improve adherence to oral medication in type 2 diabetes patients who are real time electronically monitored. Int J Med Inform 2012; 81: 594-604.

18. Vervloet M, Linn AJ, van Weert JCM, de Bakker DH, Bouvy ML, van Dijk L. The effectiveness of interventions using electronic reminders to improve adherence to chronic medication: a systematic review of the literature. J Am Med Inform Assoc 2012; 19: 696-704.

19. Vervloet M, van Dijk L, de Bakker DH, Souverein PC, Santen-Reestman J, van Vlijmen B, et al. Short- and long-term effects of real-time medication monitoring with short message service (SMS) reminders for missed doses on the refill adherence of people with Type 2 diabetes: evidence from a randomized controlled trial. Diabet Med 2014; 31: 821-8.

20. Vervloet M, van Dijk L, Santen-Reestman J, van Vlijmen B, Bouvy ML, de Bakker $\mathrm{DH}$. Improving medication adherence in diabetes type 2 patients through Real Time Medication Monitoring: a Randomised Controlled Trial to evaluate the effect of monitoring patients' medication use combined with short message service (SMS) reminders. BMC Health Serv Res 2011; 11: 5.

21. Bogner HR, Morales KH, de Vries HF, Cappola AR. Integrated management of type 2 diabetes mellitus and depression treatment to improve medication adherence: a randomized controlled trial. Ann Fam Med 2012; 10: 15-22.

22. Steiner JF, Prochazka AV. The assessment of refill compliance using pharmacy records: Methods, validity, and applications. Journal of Clinical Epidemiology. 1997;50(1):105-116. 
23. Guldberg TL, Vedsted P, Kristensen JK, Lauritzen T. Improved quality of Type 2 diabetes care following electronic feedback of treatment status to general practitioners: a cluster randomized controlled trial. Diabet Med 2011; 28: 325-32. 
ONLINE APPENDIX 3. DEGREE OF USE OF THEORY IN THE DEVELOPMENT OF THE INTERVENTIONS*

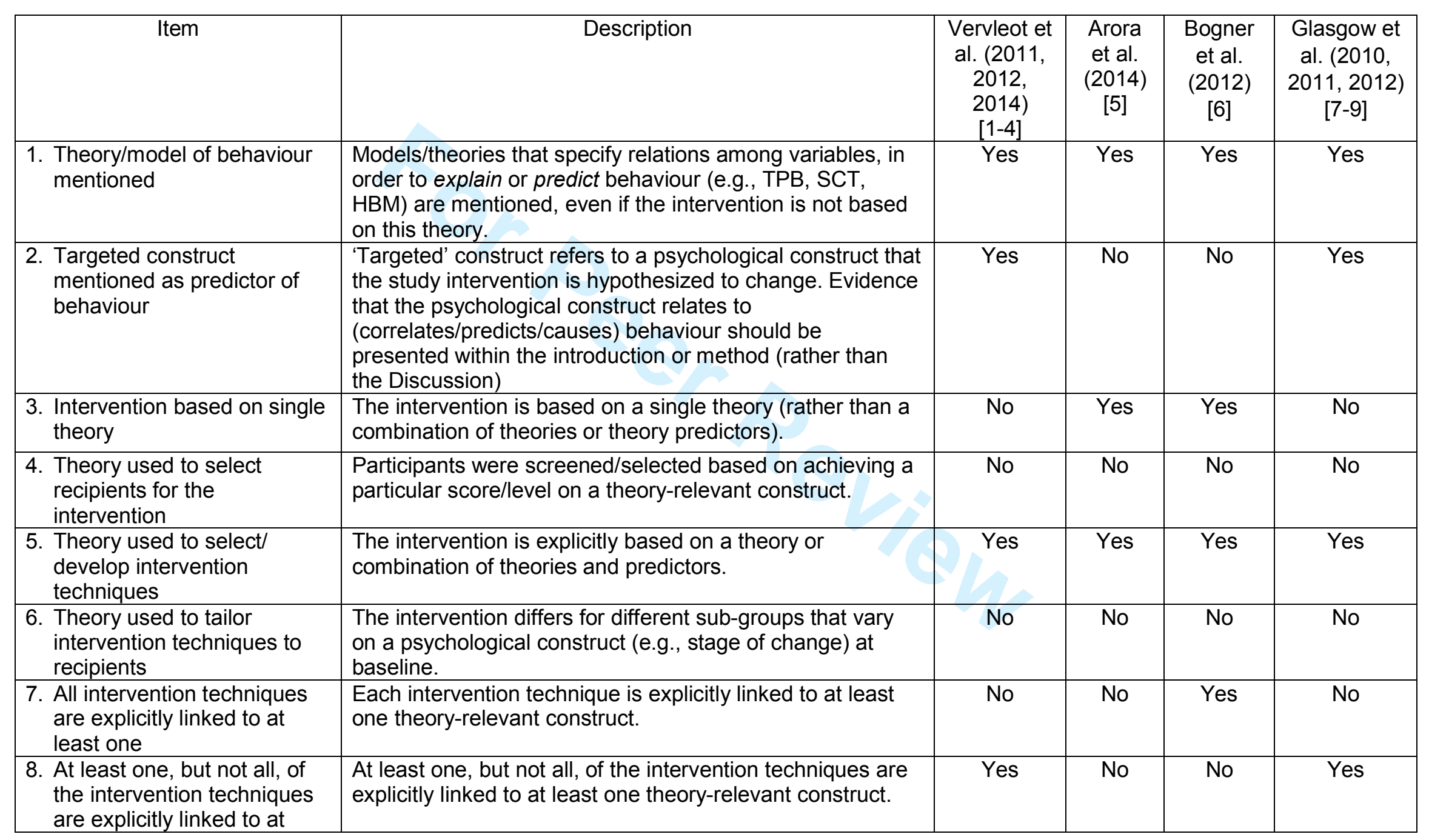




\begin{tabular}{|c|c|c|c|c|c|}
\hline $\begin{array}{l}\text { least one theory-relevant } \\
\text { construct }\end{array}$ & & & & & \\
\hline \multirow[t]{2}{*}{$\begin{array}{l}\text { 12. Theory-relevant constructs } \\
\text { are measured }\end{array}$} & $\begin{array}{l}\text { (a) At least one construct of theory mentioned in relation to } \\
\text { the intervention is measured post-intervention. }\end{array}$ & No & No & No & Yes \\
\hline & $\begin{array}{l}\text { (b) At least one construct of theory mentioned in relation to } \\
\text { the intervention is measured pre- and post- intervention. }\end{array}$ & No & No & No & Yes \\
\hline \multirow{4}{*}{ 13. Quality of measures } & $\begin{array}{l}\text { (c) All of the measures of theory relevant constructs have } \\
\text { been previously validated. }\end{array}$ & No & No & No & No \\
\hline & $\begin{array}{l}\text { (d) At least one, but not all, of the measures of theory } \\
\text { relevant constructs have been previously validated }\end{array}$ & No & No & No & No \\
\hline & $\begin{array}{l}\text { (e) The behaviour measure had some evidence for its } \\
\text { reliability }\end{array}$ & Yes & No & Yes & Yes \\
\hline & (f) The behaviour measure has been previously validated. & Yes & Yes & Yes & No \\
\hline \multirow{4}{*}{$\begin{array}{l}\text { 14. Randomization of } \\
\text { participants to condition }\end{array}$} & (a) Do the authors claim randomization? & Yes & Yes & Yes & Yes \\
\hline & $\begin{array}{l}\text { (b) Is a method of random allocation to condition described } \\
\text { (e.g., random number generator; coin toss). }\end{array}$ & Yes & Yes & Yes & Yes \\
\hline & (c) Was the success of randomization tested? & Yes & Yes & Yes & Yes \\
\hline & (d) Was the randomization successful (or baseline & Yes & No & Yes & Yes \\
\hline
\end{tabular}




\begin{tabular}{|c|c|c|c|c|c|}
\hline & $\begin{array}{l}\text { differences between intervention and control group } \\
\text { statistically controlled)? }\end{array}$ & & & & \\
\hline \multirow{2}{*}{$\begin{array}{l}\text { 16. Mediational analysis of } \\
\text { construct(s) }\end{array}$} & (b) Mediator predicts DV (when controlling for IV)? & No & No & No & No \\
\hline & $\begin{array}{l}\text { (c) Intervention does not predict DV (when controlling for } \\
\text { mediator)? }\end{array}$ & No & No & No & No \\
\hline $\begin{array}{l}\text { 17. Results discussed in } \\
\text { relation to theory }\end{array}$ & $\begin{array}{l}\text { Results are discussed in terms of the theoretical basis of } \\
\text { the intervention }\end{array}$ & No & No & No & No \\
\hline $\begin{array}{l}\text { 18. Appropriate support for } \\
\text { theory }\end{array}$ & $\begin{array}{l}\text { Support for the theory is based on appropriate mediation } \\
\text { OR refutation of the theory is based on obtaining } \\
\text { appropriate null effects (i.e. changing behaviour without } \\
\text { changing the theory-relevant constructs) }\end{array}$ & No & No & No & No \\
\hline $\begin{array}{l}\text { 19. Results used to refine } \\
\text { theory }\end{array}$ & $\begin{array}{l}\text { The authors attempt to refine the theory upon which the } \\
\text { intervention was based by either: } \\
\text { a) adding or removing constructs to the theory, or }\end{array}$ & No & No & No & No \\
\hline
\end{tabular}

${ }^{*}$ Extent to which the interventions are theory-based, examined by using the theory coding scheme developed by Michie et al [10].Information reported only for the four trials that reported the use of a theoretical model for the development of the intervention(s) (item $1=$ yes). DV = dependent variable; IV= independent variable; HBM =Health Belief Model; SCT =Social Cognitive Theory; TPB =Theory of Planned Behaviour 


\section{REFERENCES}

1. Vervloet M, Dijk L, Santen-Reestman J, Vlijmen B, Wingerden P, Bouvy ML, et al. SMS reminders improve adherence to oral medication in type 2 diabetes patients who are real time electronically monitored. . Int J Med Inform 2012; 81: 594-604.

2. Vervloet M, Linn AJ, van Weert JCM, de Bakker DH, Bouvy ML, van Dijk L. The effectiveness of interventions using electronic reminders to improve adherence to chronic medication: a systematic review of the literature. J Am Med Inform Assoc 2012; 19: 696-704.

3. Vervloet M, van Dijk L, de Bakker DH, Souverein PC, Santen-Reestman J, van Vlijmen B, et al. Short- and long-term effects of real-time medication monitoring with short message service (SMS) reminders for missed doses on the refill adherence of people with Type 2 diabetes: evidence from a randomized controlled trial. Diabet Med 2014; 31: 821-8. 4. Vervloet M, van Dijk L, Santen-Reestman J, van Vlijmen B, Bouvy ML, de Bakker $\mathrm{DH}$. Improving medication adherence in diabetes type 2 patients through Real Time Medication Monitoring: a Randomised Controlled Trial to evaluate the effect of monitoring patients' medication use combined with short message service (SMS) reminders. BMC Health Serv Res 2011; 11: 5.

5. Arora S, Peters AL, Burner E, Lam CN, Menchine M. Trial to examine text messagebased mHealth in emergency department patients with diabetes (TExT-MED): a randomized controlled trial. Ann Emerg Med 2014; 63: 745-54.

6. Bogner HR, Morales KH, de Vries HF, Cappola AR. Integrated management of type 2 diabetes mellitus and depression treatment to improve medication adherence: a randomized controlled trial. Ann Fam Med 2012; 10: 15-22.

7. Glasgow R, Christiansen SM, Kurz D, King DK, Woolley T, Faber AJ, et al. Engagement in a diabetes self-management website: usage patterns and generalizability of program use. J Med Internet Res

8. Glasgow RE, Kurz D, King D, Dickman JM, Faber AJ, Halterman E, et al. Outcomes of minimal and moderate support versions of an internet-based diabetes self-management support program. J Gen Intern Med 2010; 25: 1315-22.

9. Glasgow RE, Kurz D, King D, Dickman JM, Faber AJ, Halterman E, et al. Twelvemonth outcomes of an Internet-based diabetes self-management support program. Patient Educ Couns 2012; 87: 81-92.

10. Michie S, Prestwich A. Are interventions theory-based? Development of a theory coding scheme. Health Psychol 2010; 29: 1-8. 


\section{ONLINE APPENDIX 4. FUNNEL PLOT}

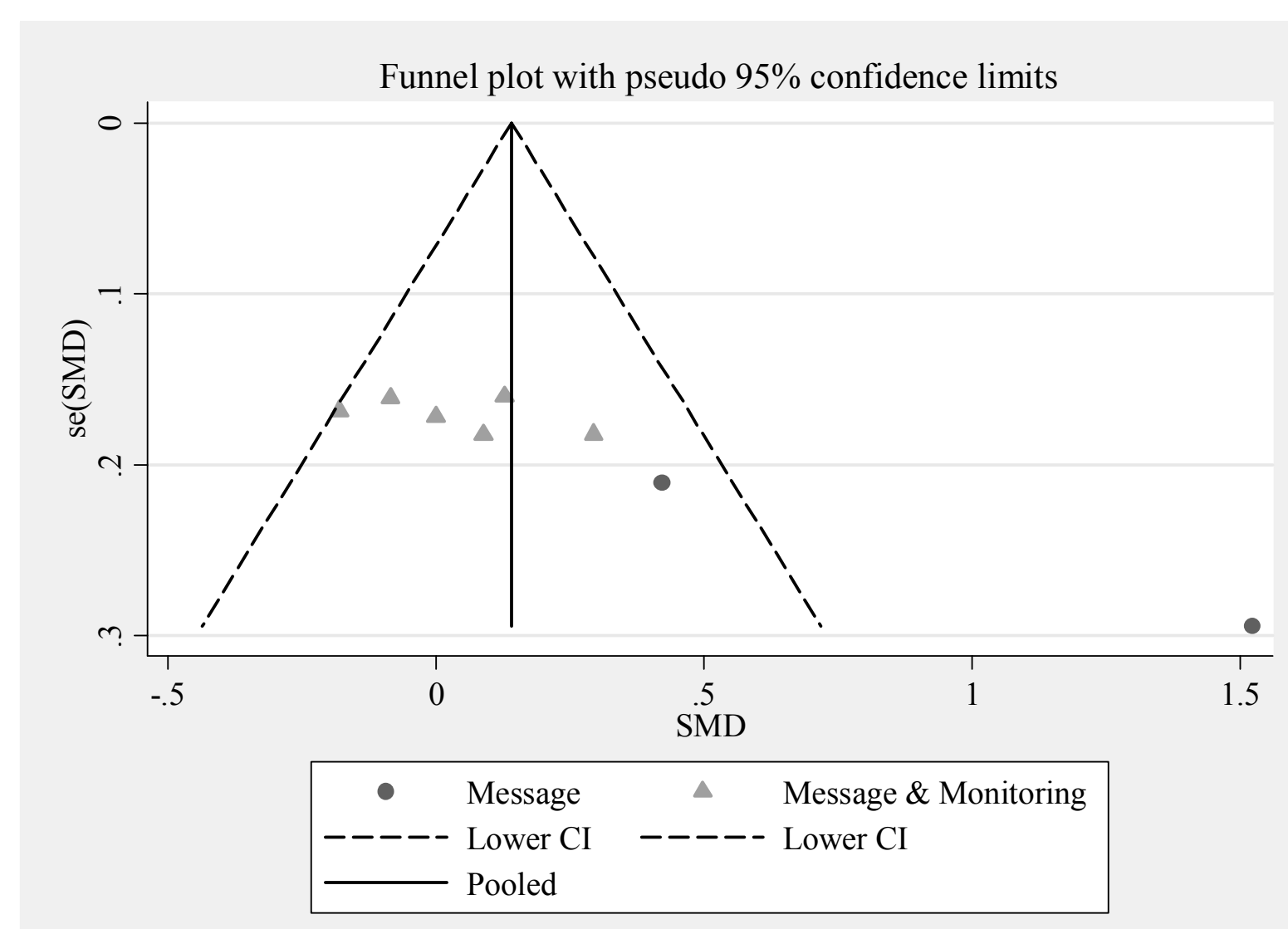

SMD, standardized mean difference; se, standard error; $\mathrm{Cl}$, confidence interval. 